\title{
IGRANIE Z OGNIEM - RYTUAŁY POGRZEBOWE KULTURY STRZYŻOWSKIEJ NA PRZYKŁADZIE WYBRANYCH POCHOWKÓW Z CMENTARZYSKA W ROGALINIE**
}

\author{
PLAYING WITH FIRE - FUNERARY RITUALS OF THE STRZYŻÓW \\ CULTURE AS EXEMPLIFIED BY SELECTED GRAVES \\ FROM THE CEMETERY IN ROGALIN, POLAND
}

The text presents newly discovered graves of Strzyżów culture from the Early Bronze Age, located at a cemetery in Rogalin, Poland. The funeral rites of Strzyżów culture are multifaceted. Most of the dead were placed in graves in supine position, equipped with vessels, tools, and ornaments - and then buried. This text, however, discusses burial rites involving the use of fire both in open burial pits and after burial, as well as subsequent practices of opening and disturbing graves. Analysis was supplemented by results of radiocarbon dating.

KEY WORDS: the Early Bronze Age, Strzyżów culture, grave goods, funeral rites

\section{WSTEP}

Wielokulturowe stanowisko w Rogalinie (pow. hrubieszowski, woj. lubelskie) zostało odkryte przypadkowo w 2008 roku przez mieszkańca tej miejscowości. Odnotowane przez niego na powierzchni fragmenty szkieletu oraz inne materiały zabytkowe zgłoszone zostały do Działu archeologicznego hrubie-

*Artykuł prezentuje wyniki badań przeprowadzonych w ramach projektu „Najmniej znany spośród najbardziej interesujących - obrządek pogrzebowy kultury strzyżowskiej" sfinansowanego ze środków Narodowego Centrum Nauki przyznanych na podstawie decyzji numer 2015/17/ HS3/02865. szowskiego Muzeum im. ks. Stanisława Staszica za pośrednictwem Komendy Powiatowej Policji w Hrubieszowie. Powierzchniowa weryfikacja doniesienia o odkryciu oraz charakter odkrytych wówczas zabytków potwierdziły obecność we wskazanym miejscu zniszczonego pochówku oraz tym samym konieczność przeprowadzenia badań ratowniczych.

Stanowisko znajduje się na terenie eksponowanym $\mathrm{w}$ strefie krawędziowej doliny Bugu, na stoku opadającym w kierunku południowym, w obrębie mezoregionu Grzędy Horodelskiej, w zachodniej części Wyżyny Wołyńskiej (ryc. 1, 2). Teren, na którym ulokowane jest stanowisko, położony jest na terasie zalewowej najwyższej w obrębie garbu lessowego (Rodzik, Mroczek 2015, 82-84). Współcześnie obszar jest systematycznie uprawianą działką rolną, 


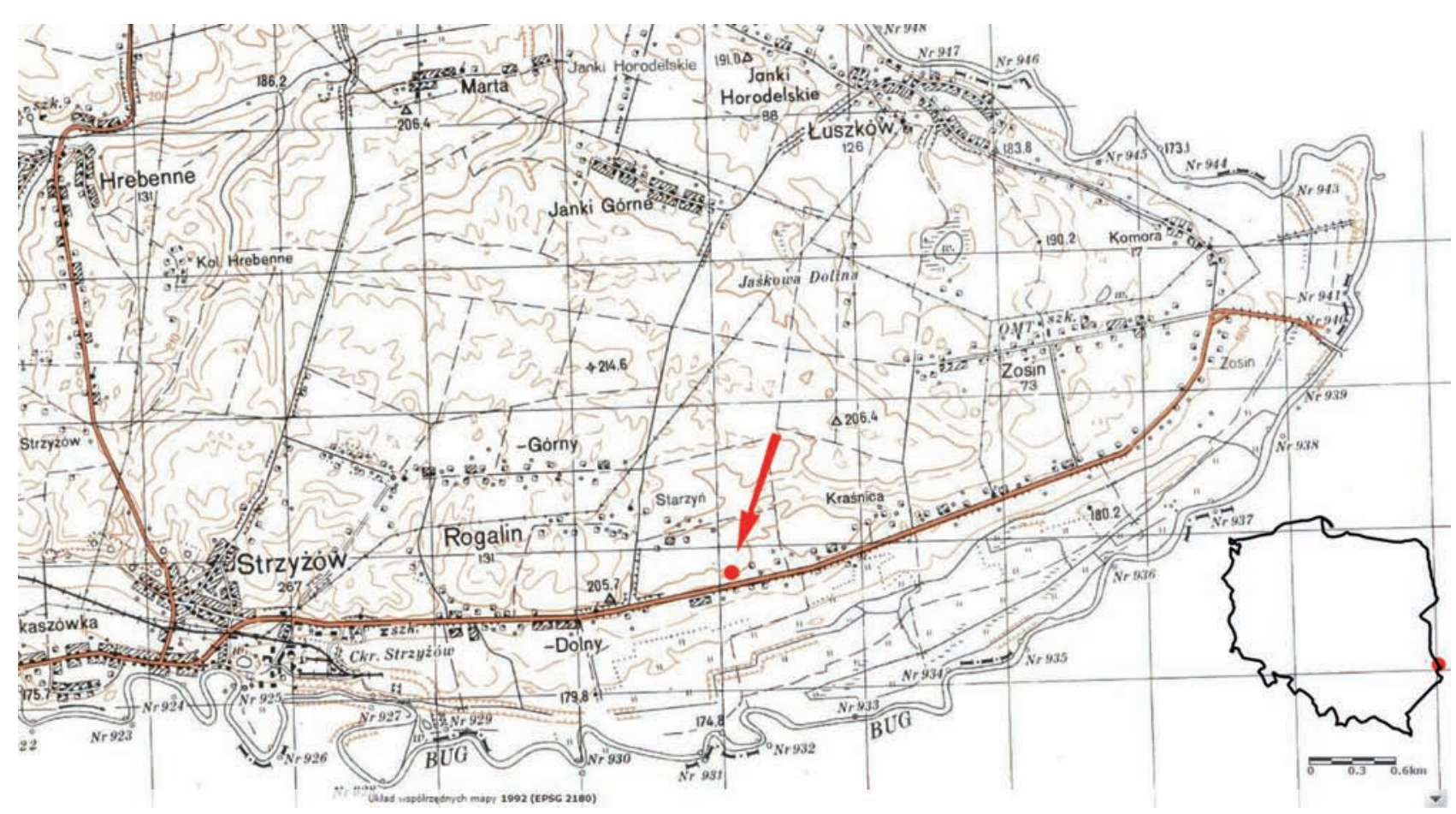

Ryc. 1. Lokalizacja stanowiska 15 w Rogalinie. Źródło mapy: geoportal.gov.pl

Fig. 1. Location of site no. 15 in Rogalin. Map source: geoportal.gov.pl

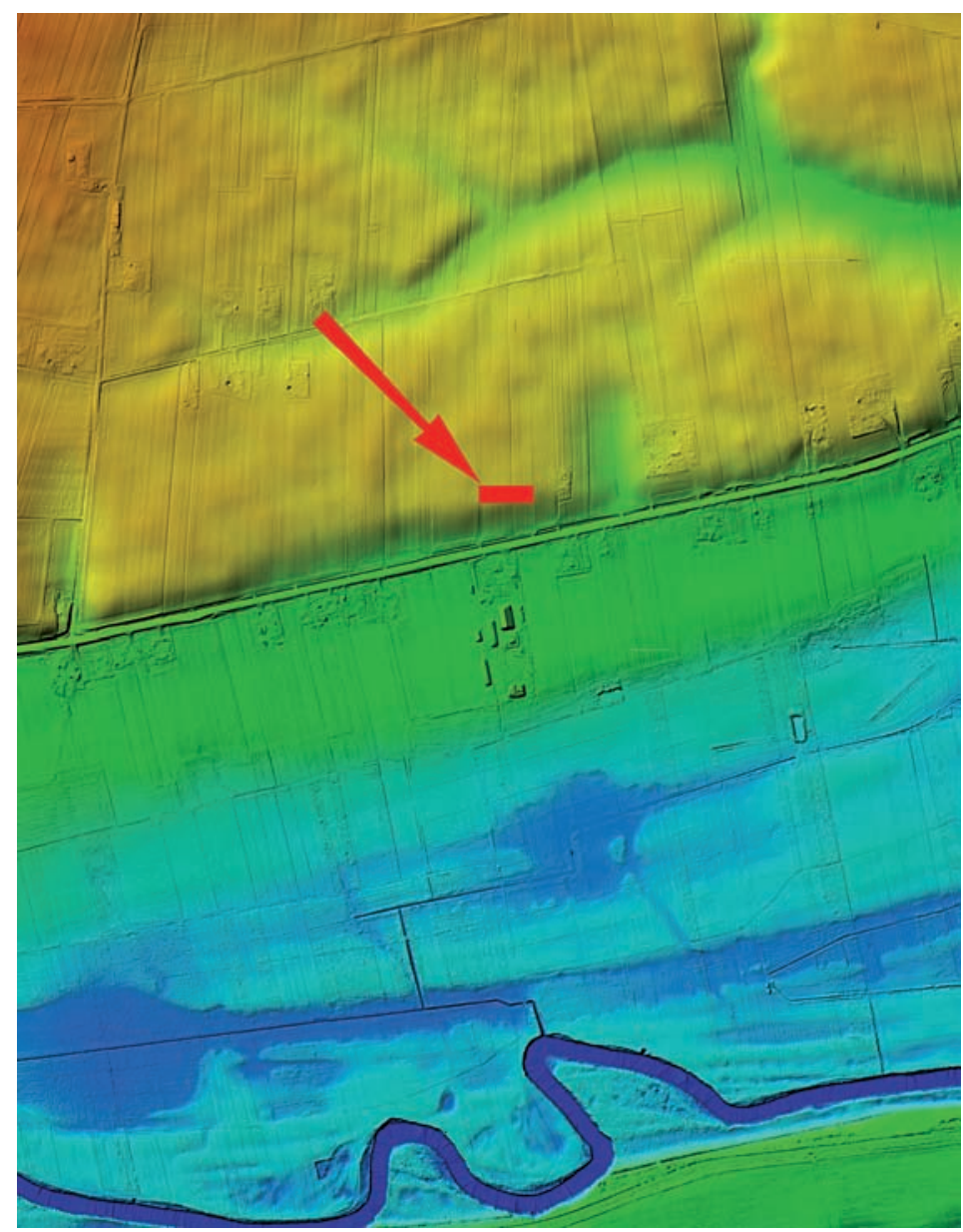

Ryc. 2. Lokalizacja obszaru badań na stanowisku nr 15 w Rogalinie Fig. 2. Location of the excavation area of site no. 15 in Rogalin 


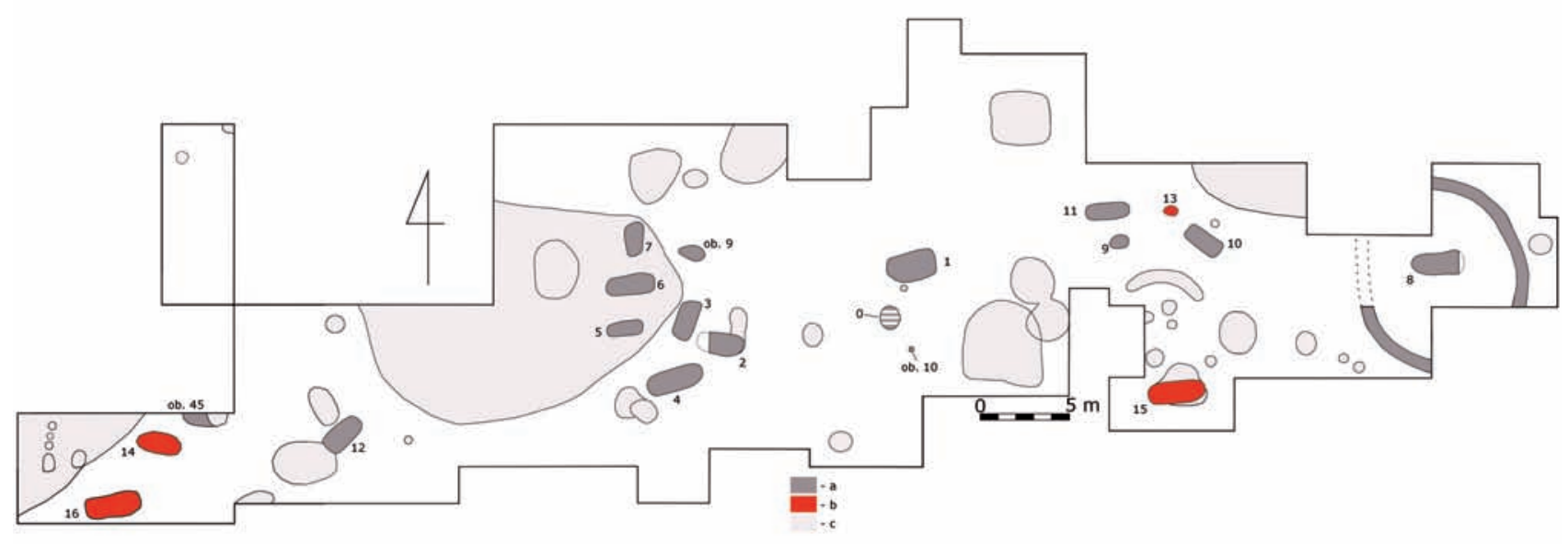

Ryc. 3. Rogalin stan. 15. Plan cmentarzyska: a - obiekty kultury strzyżowskiej; b - groby kultury strzyżowskiej będące przedmiotem opracowania; c - obiekty innych kultur

Fig. 3. Rogalin site 15. Plan of the cemetery: a - features of the Strzyżów culture; b - graves of the Strzyżów culture discussed in the article; $\mathrm{c}$ - features of other cultures

przeważnie obsiewany kukurydzą lub pszenicą. Dodatkowo poddawany jest stałej erozji stokowej. W wyniku obu tych czynników pierwotna rzeźba terenu została zaburzona (Rodzik, Mroczek 2015, 86-88). Powoduje to, że stan zachowania obiektów jest bardzo zróżnicowany, a ich stropy często są słabo czytelne, również z uwagi na działalność zwierząt ryjących.

W latach 2009-2016 na stanowisku nr 15 w Rogalinie regularnie prowadzone były prace wykopaliskowe z ramienia muzeum w Hrubieszowie, przy współpracy z Instytutem Archeologii Uniwersytetu Marii Curie-Skłodowskiej w Lublinie. W ciągu siedmiu sezonów przebadano łącznie $1105,5 \mathrm{~m}^{2}$ powierzchni w obrębie 43 wykopów. Odkryto 47 obiektów związanych z neolitycznymi kulturami pucharów lejkowatych i amfor kulistych, kulturą trzciniecką datowaną na epokę brązu oraz 16 grobów kultury strzyżowskiej z wczesnego okresu epoki brązu. Groby nr 1-12 zostały opublikowane w 2015 roku (Hyrchała 2015a, 52-79).

$\mathrm{Na}$ cmentarzyskach kultury strzyżowskiej jamy grobowe usytuowane były głównie na osi wschódzachód. Zmarłych, wyposażonych w dary grobowe, składano do grobów w pozycji wyprostowanej. Jednak w kilku przypadkach odkryto, odbiegające od tego kanonu, interesujące praktyki pogrzebowe. W literaturze przedmiotu pojawiają się pojedyncze przypadki, omawiające szkielety ze śladami nadpalenia, a także wzmianki o spalonym drewnie, fragmentach węgli i polepy w zasypiskach jam grobowych (Ślusarski, Ślusarska-Polańska 1988, 181, 188; Polańska 1994, 16-17). Przebadane w Rogalinie w latach 2015-
2016 pochówki kultury strzyżowskiej (groby nr 13-16, ryc. 3) stanowią przedmiot niniejszego opracowania i dostarczają nowych informacji na temat rekonstrukcji rytuałów pogrzebowych z użyciem ognia.

\section{CHARAKTERYSTYKA ODKRYTYCH POCHÓWKÓW}

Część obiektów odkryta została tuż pod powierzchnią oraniny $\mathrm{z}$ wyraźnymi śladami zniszczeń dokonanych przez maszyny rolnicze (groby $\mathrm{nr}$ 14, 15, 16). Pochówki, których stropy znajdowały się na głębokości $40 \mathrm{~cm}$ od obecnej powierzchni gruntu, należy uznać za dobrze zachowane (grób nr 13).

\section{Grób nr 13 (ryc. 4, 5)}

Jama grobowa owalnego kształtu usytuowana była na osi NW-SE. Jej strop odkryto na głębokości $40 \mathrm{~cm}$ od obecnej powierzchni gruntu, a wymiary wynosiły 160 x $90 \mathrm{~cm}$. Pochowano w niej dziecko w wieku infans I (około 6-7 miesięcy). Niepełny profil genetyczny szczątków z grobu wskazuje, że należały one do osobnika płci żeńskiej (Lorkiewicz-Muszyńska et al., w tym tomie). Zachowany fragmentarycznie szkielet ułożony był w pozycji wyprostowanej na plecach z głową na zachód. W zachodniej części jamy grobowej ustawiono trzy naczynia ornamentowane w sposób charakterystyczny dla kultury strzyżowskiej. Pierwsze z nich to dwuucha amfora zdobiona odciskami sznura w układzie poziomym na wylewie, 

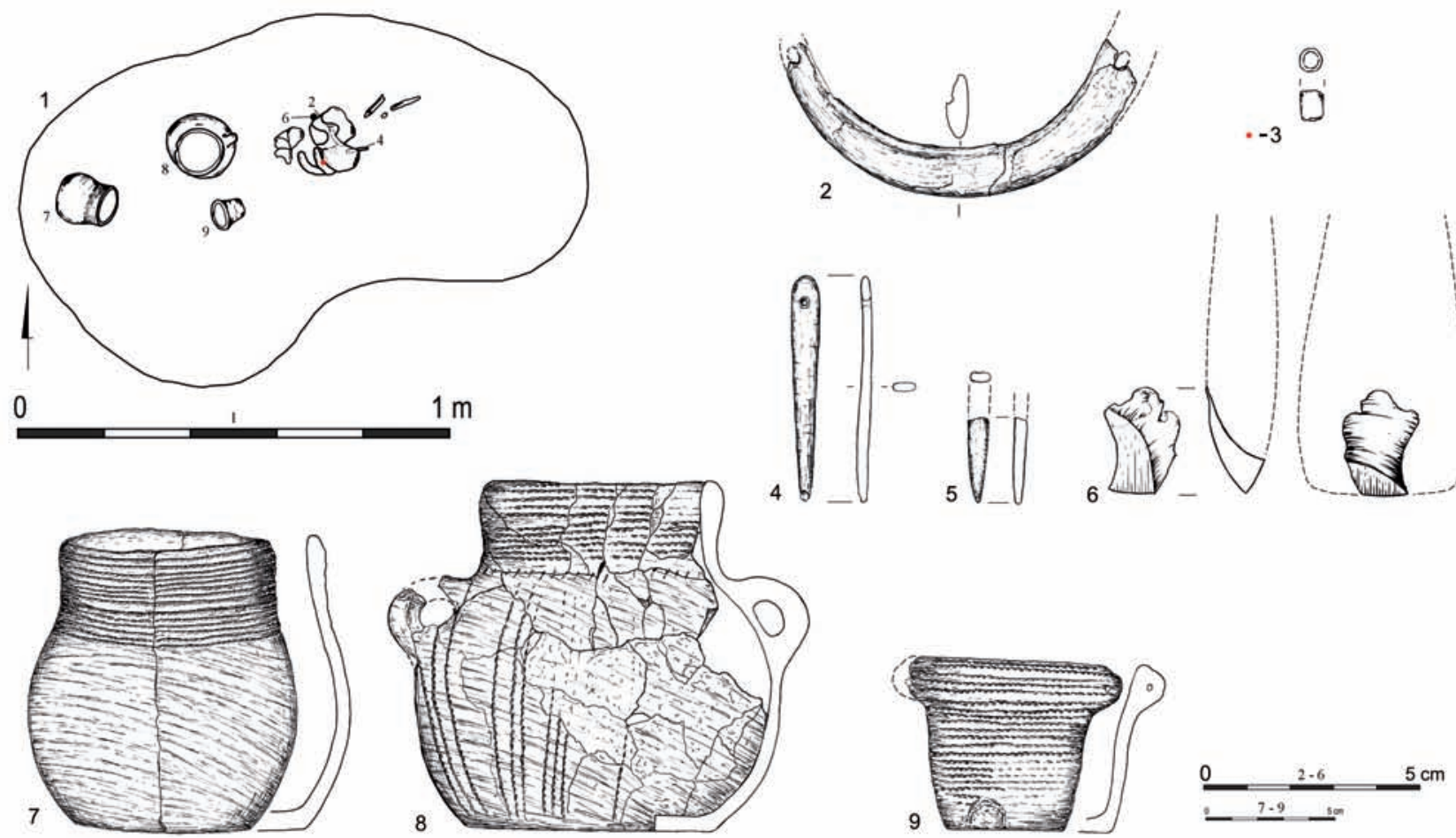

Ryc. 4. Rogalin stan. 15. Plan grobu 13 z wyposażeniem. Rys. B. Bartecki

Fig. 4. Rogalin site 15. Plan of grave 13 with furnishings. Figure by B. Bartecki

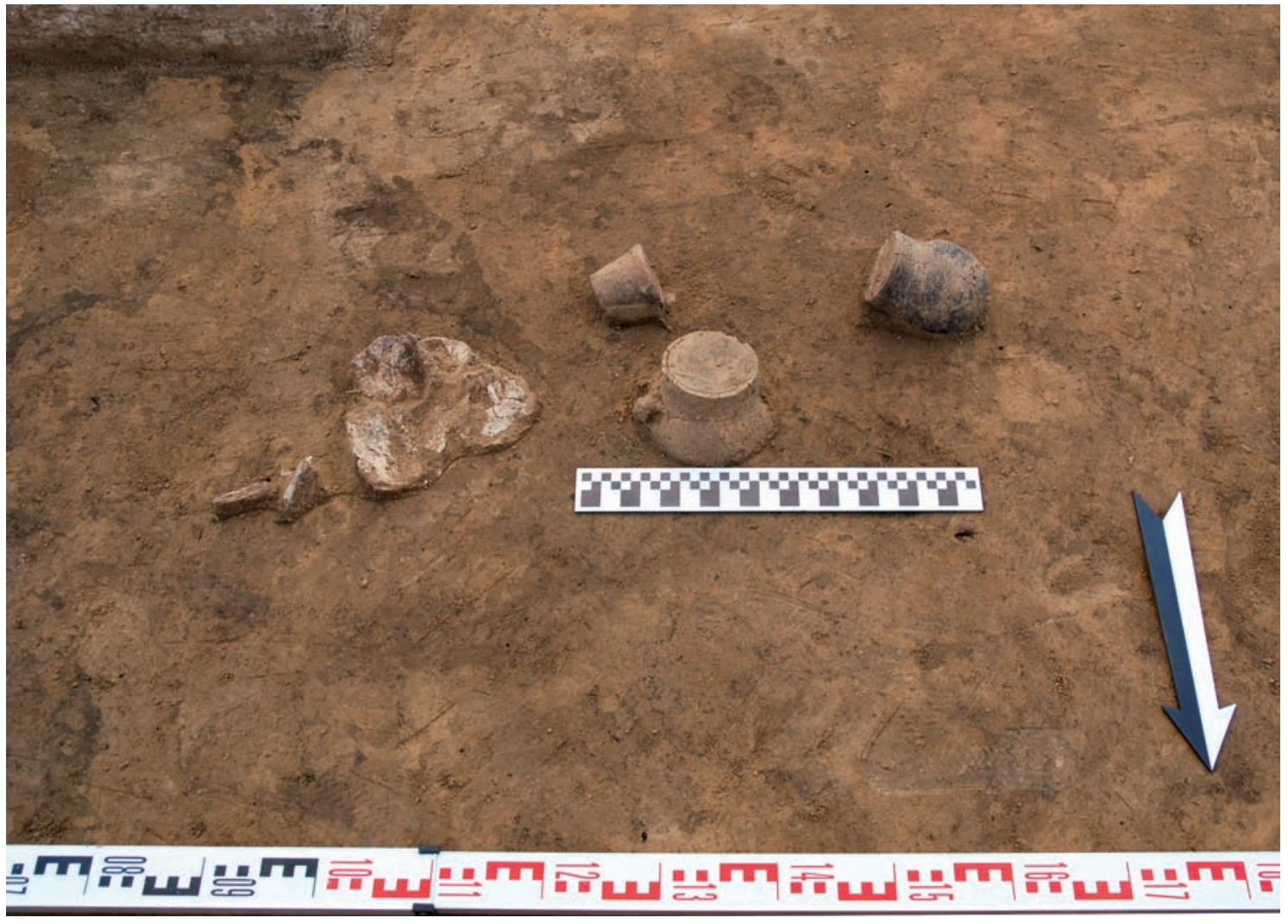

Ryc. 5. Rogalin stan. 15. Grób 13. Fot. A. Hyrchała

Fig. 5. Rogalin site 15. Grave 13. Photo by A. Hyrchała 
w układzie pionowym na brzuścu (ryc. 4: 8). Naczynie było bardzo słabo wypalone, przez co nie zachowało się w całości. Wymiary: wysokość $13,3 \mathrm{~cm}$, średnica wylewu 9,4 cm, brzuśca 14,1 cm, dna 9,3 cm. Drugie z odkrytych naczyń to niewielki pucharek z dwoma poziomo przekłutymi uszkami przy wylewie, zdobiony na całej powierzchni odciskami sznura w układzie poziomym (ryc. 4: 9). Wymiary: wysokość $6,5 \mathrm{~cm}$, średnica wylewu $8,8 \mathrm{~cm}$, dna $4,4 \mathrm{~cm}$. Trzecim naczyniem był garnek o esowatym profilu zdobiony na wylewie odciskami sznura w układzie poziomym (ryc. 4: 7). Wymiary: wysokość $11,5 \mathrm{~cm}$, średnica wylewu $8,3 \mathrm{~cm}$, brzuśca $10,3 \mathrm{~cm}$, dna $6,7 \mathrm{~cm}$. W skład darów grobowych weszły także zabytki kościane odkryte w okolicach czaszki. Zmarła wyposażona była w zawieszkę wykonaną z szabli dzika z otworkami na obu końcach (długość 8,1 cm) (ryc. 4: 2), pełniącą zapewne funkcję naszyjnika oraz dwie szpile kościane, z których jedna zachowała się we fragmencie (długość $5,2 \mathrm{~cm}$ i $2 \mathrm{~cm}$ ) (ryc. 4: 4, 5) i paciorek fajansowy (ryc.
4: 3). Bezpośrednio przy szkielecie dziecka odkryto odłupek z przyostrzowej części gładzonej siekiery krzemiennej (ryc. 4: 6).

\section{Grób nr 14 (ryc. 6)}

Wykop, w obrębie którego odkryto następny pochówek, wytyczony został w miejscu, w którym na powierzchni pola zauważalna była duża ilość polepy. Tuż pod warstwą oraniny na głębokości $25 \mathrm{~cm}$ odkryto owalną jamę o wymiarach $250 \times 110 \mathrm{~cm}$, zorientowaną na osi NW-SE, której wypełnisko stanowiło przemieszaną brązowo-szaro-pomarańczową ziemię z bryłami polepy i węglami (ryc. 7). Pod warstwą polepy odkryto 679 przepalonych fragmentów kości dziecka w wieku infans I/infans II (około 7 lat) (Lorkiewicz-Muszyńska et al., w tym tomie). Na podstawie zachowanych w porządku anatomicznym szczątków kończyn dolnych oraz skupiska przepalonych kości czaszki wiadomo, że osobnik ułożony został w pozycji na wznak, z głową na wschód. Dziecko
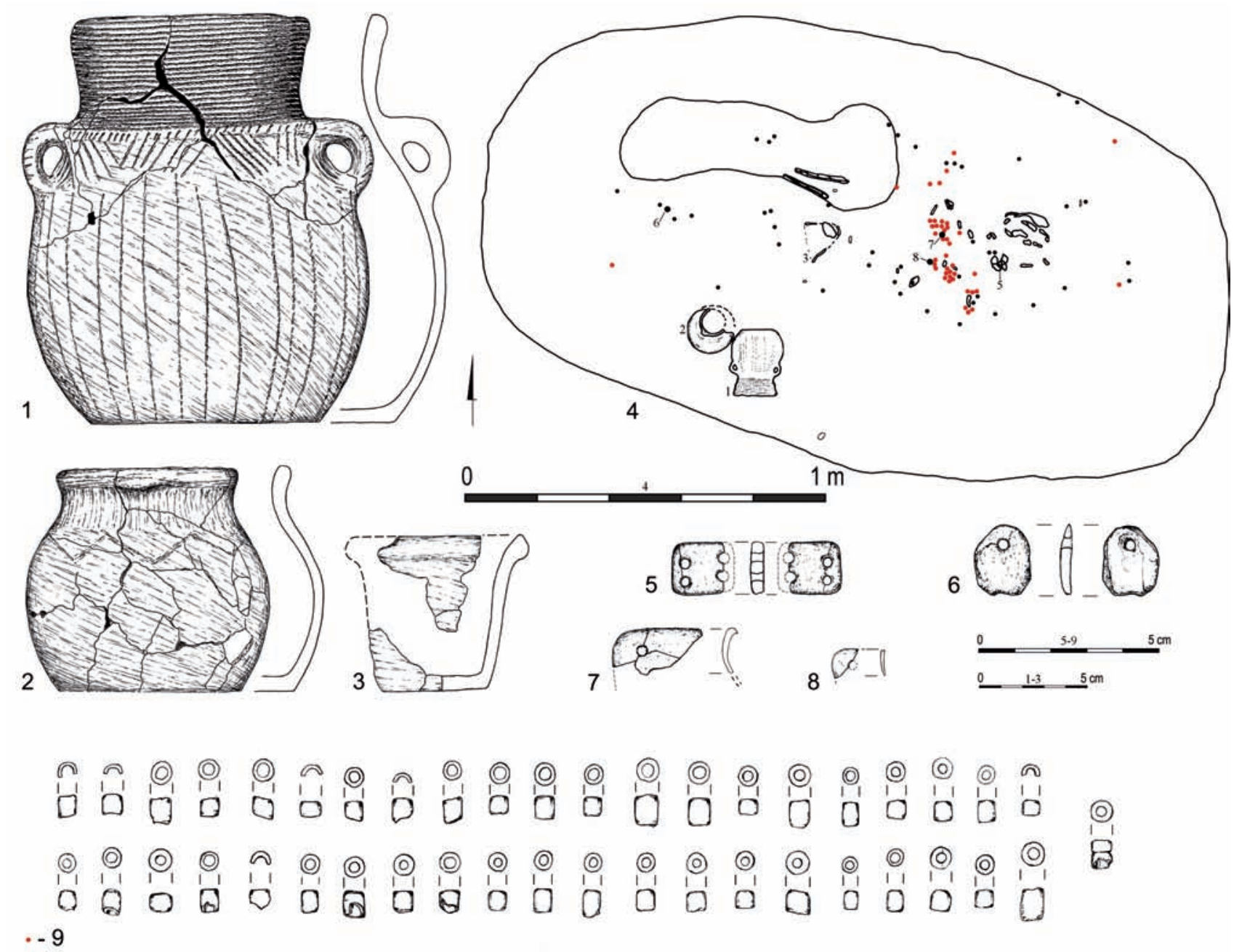

Ryc. 6. Rogalin stan. 15. Plan grobu 14 z wyposażeniem. Rys. B. Bartecki

Fig. 6. Rogalin site 15. Plan of grave 14 with furnishings. Figure by B. Bartecki 


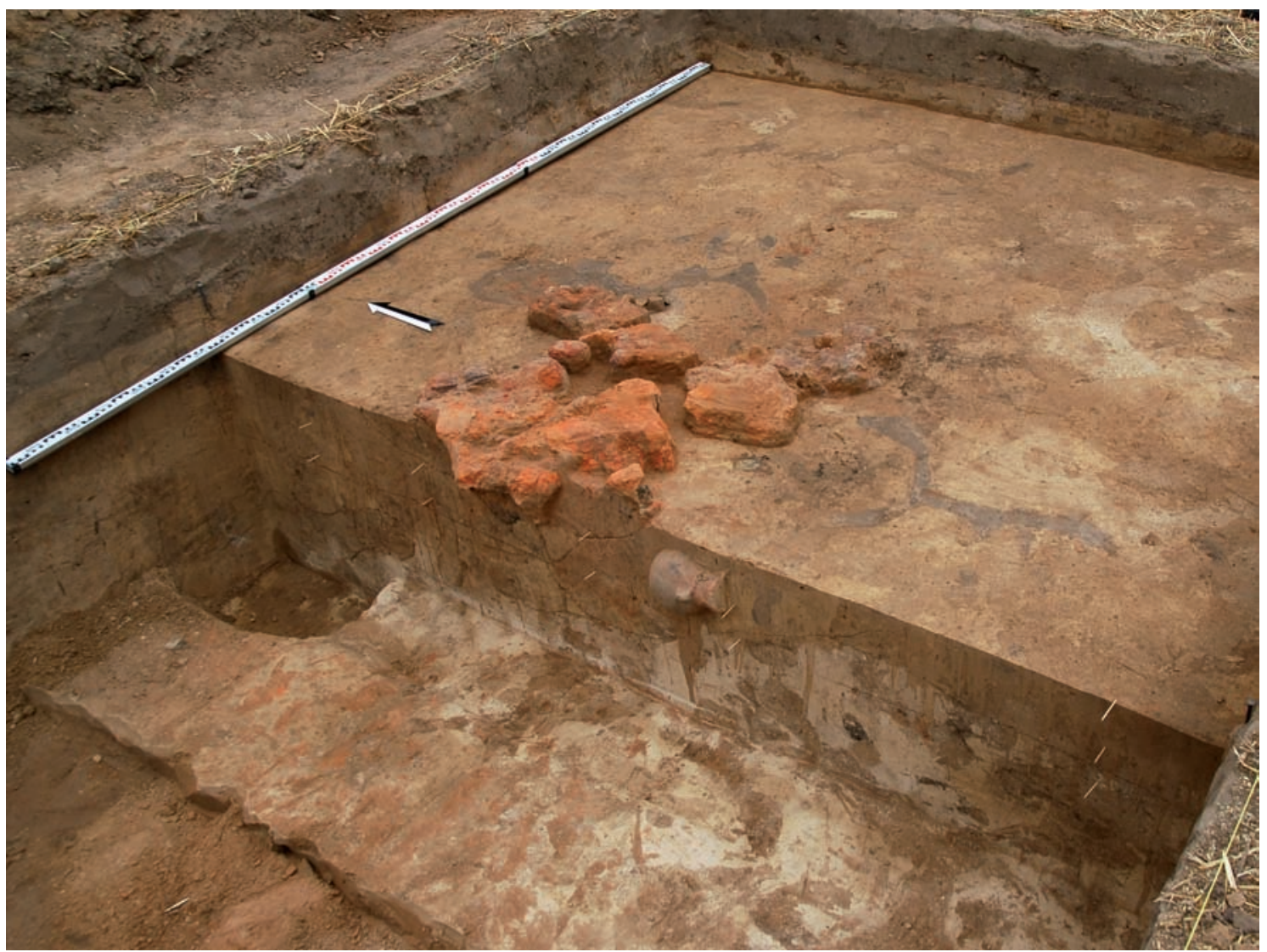

Ryc. 7. Rogalin stan. 15. Warstwa polepy nad szkieletem w grobie 14. Fot. A. Hyrchała

Fig. 7. Rogalin site 15. Layer of daub over the skeletal remains in grave 14. Photo by A. Hyrchała

wyposażono w trzy naczynia gliniane w różnym stanie zachowania. W południowej części jamy grobowej ustawione były dwa z nich, a trzecie, słabo zachowane, odkryto przy kościach nóg (ryc. 8). Pierwsze z naczyń, o esowatym profilu, zdobione było słabo czytelnym dookolnym ornamentem w górnej partii brzuśca, w postaci opadających wierzchołkami trójkątów, wykonanym za pomocą chropowacenia (ryc. 6: 2). Na pogrubionym wylewie zachował się jeden z zapewne dwóch położonych naprzeciwlegle guzków. Za formę ornamentu uznać można również regularne, pionowe przecieranie powierzchni naczynia tuż pod wylewem. Wymiary: wysokość 10,3 cm, średnica wylewu $8,4 \mathrm{~cm}$, brzuśca $11,2 \mathrm{~cm}$, dna $8,4 \mathrm{~cm}$. Drugie z naczyń to dwuucha amfora zdobiona na szyjce odciskami sznura w układzie poziomym, na przejściu szyjki w brzusiec krótkimi ukośnymi kreskami, a na brzuścu liniami w układzie pionowym (ryc. 6: 1). Poziomy ornament sznurowy czytelny jest również na uchach naczynia. Wymiary: wysokość $18,7 \mathrm{~cm}$, średnica wylewu $11,0 \mathrm{~cm}$, brzuśca $15,8 \mathrm{~cm}$, dna 10,5 cm. Trzecie naczynie to zachowany fragmentarycznie, niezdobiony pucharek doniczkowaty (ryc. 6: 3). Wymiary: wysokość
7,1 cm, średnica wylewu 8,5 cm, średnica dna 4,8 cm. Dodatkowo przy szkielecie znaleziono 51 paciorków fajansowych (ryc. 6: 9), zawieszkę z muszli (długość $2 \mathrm{~cm}$ ) (ryc. 6: 6), a wśród przepalonych kości odkryto fragmenty aplikacji z szabli dzika (długość 0,6 cm i 2,4 cm) (ryc. 6: 7,8), aplikację kościaną (długość 1,4 cm) (ryc. 6: 5) i drobinki miedzi.

\section{Grób nr 15 (ryc. 9, 10)}

Odkryta na głębokości $25 \mathrm{~cm}$ podłużna jama grobowa o wymiarach 280 × $90 \mathrm{~cm}$, zorientowana na osi W-E, wkopana była w neolityczny obiekt nr 13, którego część N przebadano w 2011 roku. Na poziomie odkrycia, tuż pod warstwą oraniny, w obrębie jamy grobowej wyraźnie czytelne były zniszczenia spowodowane równoległą orką. Pochowano w niej dorosłego mężczyznę w wieku maturus (45-55 lat) (Lorkiewicz-Muszyńska et al., w tym tomie). Zmarły ułożony był na wznak z głową na zachód. Kości górnej części szkieletu były przemieszane, a dolnej części (kości miednicy i kości kończyn dolnych) ułożone w porządku anatomicznym. W części zachodniej jamy grobowej odkryto dwa naczynia ze zniszczonymi gór- 


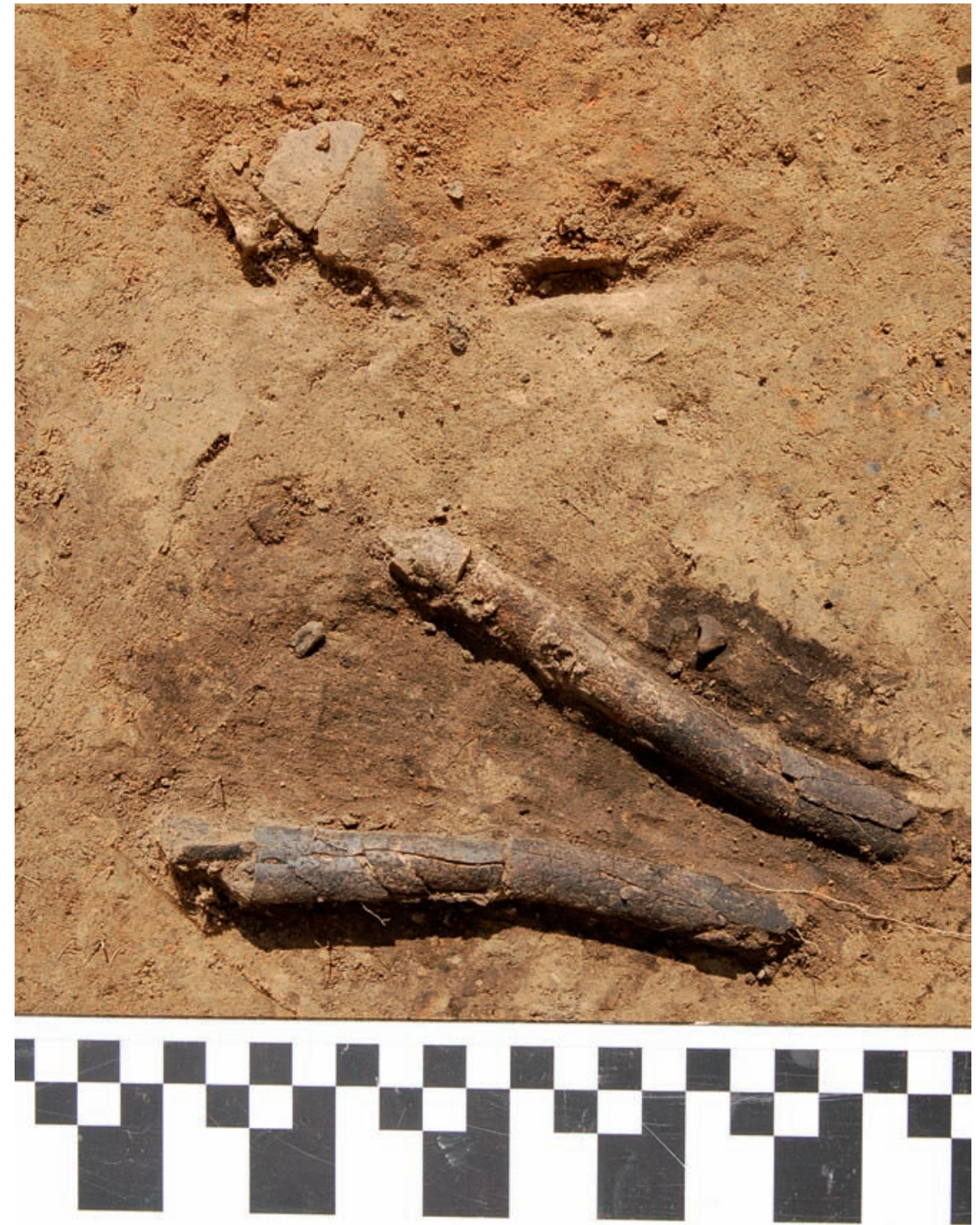

Ryc. 8. Rogalin stan. 15. Kości udowe i fragmenty naczynia w grobie 14. Fot. A. Hyrchała

Fig. 8. Rogalin site 15. Femurs and fragments of clay pots in grave 14. Photo by A. Hyrchała

nymi partiami. Pierwsze z nich, to dużych rozmiarów naczynie wazowate, którego formę oraz zdobienie udało się zrekonstruować z fragmentów (ryc. 9: 7). Brzusiec wazy jest zdobiony motywem nawiązującym do kanelur w układzie poziomym. Dodatkowo wylew oraz szyja naczynia zdobione były dookolnie odciskami sznura w układzie poziomym, natomiast na górnej części brzuśca widoczny jest ornament z ukośnych odcisków sznura układający się w romby. Wylew naczynia ornamentowany jest ukośnymi kreskami również od strony wewnętrznej. Wymiary naczynia: wysokość $28,6 \mathrm{~cm}$, średnica wylewu 32,6 cm, brzuśca $37 \mathrm{~cm}$, dna $14,2 \mathrm{~cm}$. Drugie naczynie, biorąc pod uwagę technologię, grubość ścian i stosunek średnicy brzuśca do średnicy dna, to najpewniej dwuucha amfora, ale brak fragmentów z górnej partii nie pozwala na pełną re- konstrukcję (ryc. 9: 6). Wymiary: średnica brzuśca $23 \mathrm{~cm}$, dna 13,3 cm. W obrębie jamy grobowej znaleziono również sześć paciorków fajansowych (ryc. 9: 4, 5). Zmarły wyposażony był w szpilę z kości (długość $6 \mathrm{~cm})($ ryc. 9: 2) i krzemienny grocik strzały (ryc. 9:3), odkryte po jego lewej stronie, na wysokości kości łokciowej. Interesujących informacji dostarczyły wyniki analiz antropologicznych. Na kościach kończyn zarejestrowano cechy wskazujące na wykonywanie bardzo ciężkich prac fizycznych. Mężczyzna z grobu nr 15 mógł za życia przenosić duże ciężary, a także strzelać $\mathrm{z}$ łuku. $\mathrm{Z}$ kolei inne zaobserwowane zmiany -w zakresie panewek stawów biodrowych, wskazują na częstą jazdę konną (Lorkiewicz-Muszyńska et al., w tym tomie). 
$1 \mathrm{~m}$
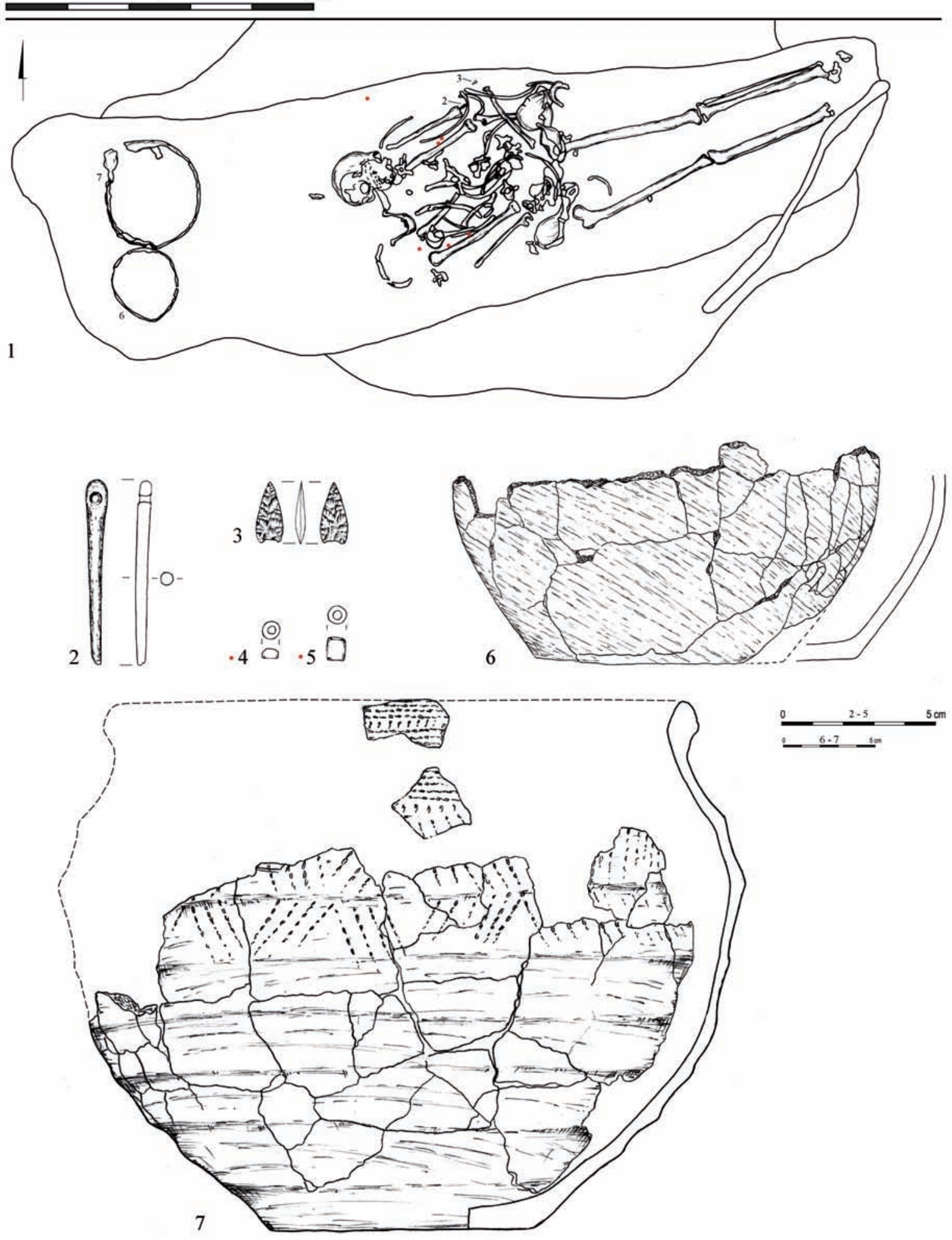

Ryc. 9. Rogalin stan. 15. Plan grobu 15 z wyposażeniem. Rys. B. Bartecki

Fig. 9. Rogalin site 15. Plan of grave 15 with furnishings. Figure by B. Bartecki

Grób nr 16 (ryc. 11, 12)

Jama grobowa kształtem zbliżona do prostokąta o zaokrąglonych narożnikach zorientowana była na osi W-E. Jej strop odkryto na głębokości $20 \mathrm{~cm}$, a wymiary wynosiły $340 \times 170 \mathrm{~cm}$. Wypełnisko stanowiła przemieszana brązowo-pomarańczowa ziemia 


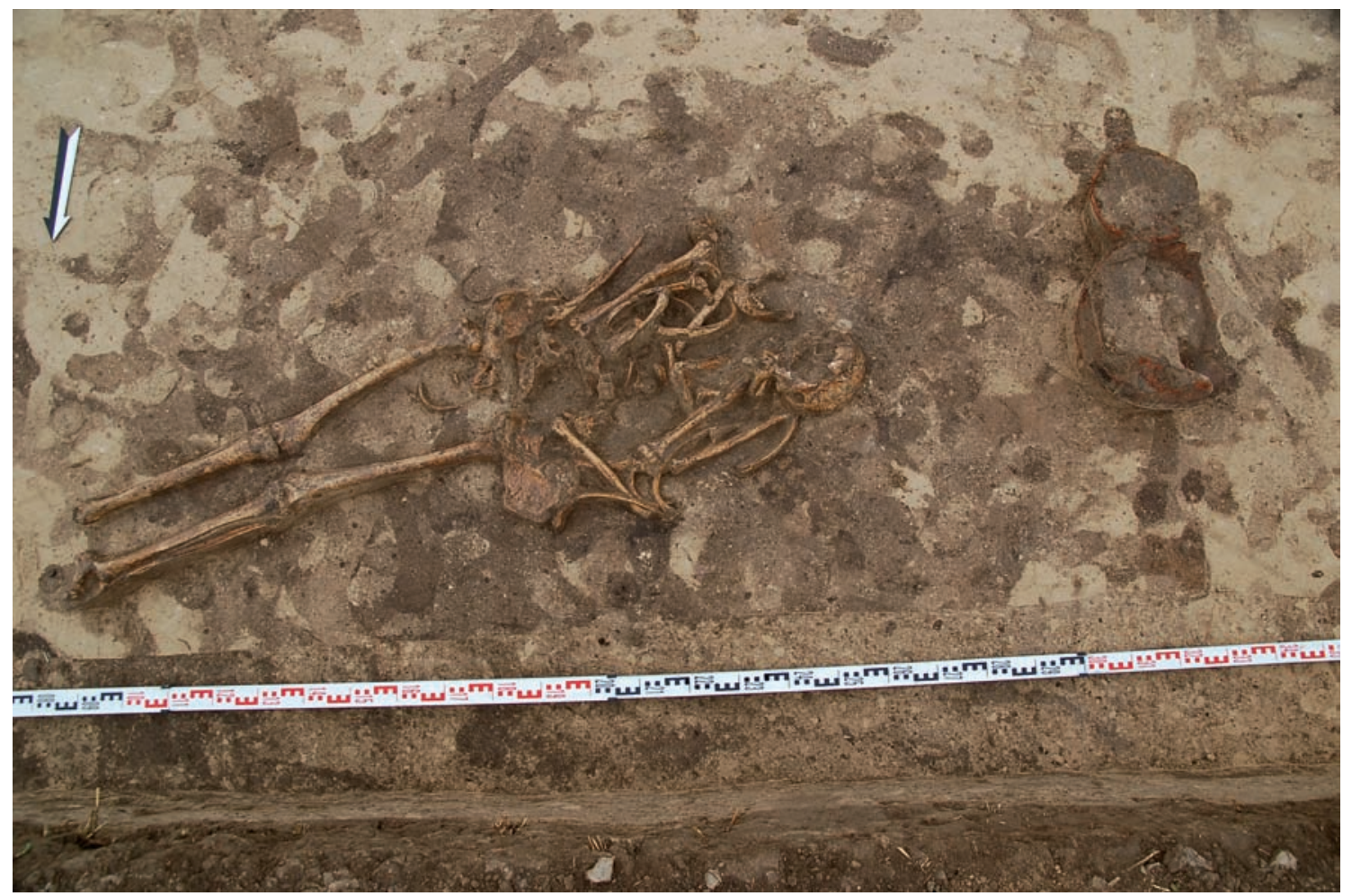

Ryc. 10. Rogalin stan. 15. Grób 15. Fot. A. Hyrchała

Fig. 10. Rogalin site 15. Grave 15. Photo by A. Hyrchała

z bryłami polepy i węglami. Na dnie jamy spoczywał szkielet dorosłego osobnika w wieku adultus (około 25-35 lat) (Lorkiewicz-Muszyńska et al., w tym tomie), w pozycji wyprostowanej na wznak, z głową na E. Szkielet nosił ślady nadpalenia, ponadto w okolicy klatki piersiowej i czaszki znajdowała się duża ilość fragmentów węgli drzewnych. W południowowschodniej części jamy grobowej ustawione były dwa naczynia. Pierwsze $z$ nich, to dwuucha amfora zdobiona na szyjce odciskami sznura w układzie poziomym, a na przejściu szyjki $\mathrm{w}$ brzusiec oraz na brzuścu w układzie zygzaków (ryc. 11: 1). Ornament sznurowy w postaci poziomych linii czytelny jest również na uchach naczynia. Wymiary: wysokość $28,9 \mathrm{~cm}$, średnica wylewu $11 \mathrm{~cm}$, brzuśca $23 \mathrm{~cm}$, dna $14 \mathrm{~cm}$. Drugie naczynie to misa z pogrubionym wylewem zaopatrzonym w cztery symetrycznie rozmieszczone guzki (ryc. 11: 2). Odciski sznura zdobią całą zewnętrzną powierzchnię naczynia, a także wylew po wewnętrznej stronie. Na brzuścu linie są odciśnięte w układzie pionowym, skąd przechodzą na dno, gdzie się krzyżują. Wymiary: wysokość $8,1 \mathrm{~cm}$, średnica wylewu $16,5 \mathrm{~cm}$, średnica dna $10,5 \mathrm{~cm}$. Dodatkowo przy szkielecie znaleziono paciorek fajansowy oraz fragment drugiego, podobnego egzemplarza, a także dwa grociki krzemienne (ryc. 11: 3-4).

\section{ANALIZA WYPOSAŻENIA GROBOWEGO}

\section{Naczynia gliniane}

W większości zespołów grobowych znajdują się naczynia gliniane, w liczbie od jednego do pięciu. Ceramika jest jednocześnie podstawowym wyznacznikiem kulturowym. Szerokodenne, przysadziste, cienkościenne amfory, charakterystycznie zdobione odciskami sznura w przeróżnych układach i obmazywane na całej powierzchni wewnętrznej i zewnętrznej wiechciem z twardych traw, trudno pomylić z naczyniami innych kultur występujących we wczesnej epoce brązu. W szczególnych wypadkach ornament sznurowy spotykany jest również na dnach naczyń oraz na wewnętrznej krawędzi wylewu. Z omówionych pochówków pochodzi dziesięć egzemplarzy. Najliczniej reprezentowane są amfory (4 naczynia), następnie naczynia esowate (2 przykłady), pucharki doniczkowate ( 2 egzemplarze) oraz jedna waza i misa. Wszystkie odkryte naczynia cechują się charakterystycznie dla kultury strzyżowskiej chropowaconą powierzchnią zewnętrzną i wewnętrzną, a na ośmiu $\mathrm{z}$ nich widoczne są dodatkowo ornamenty wykonane przez odciskanie sznura w różnych układach. Pod względem 

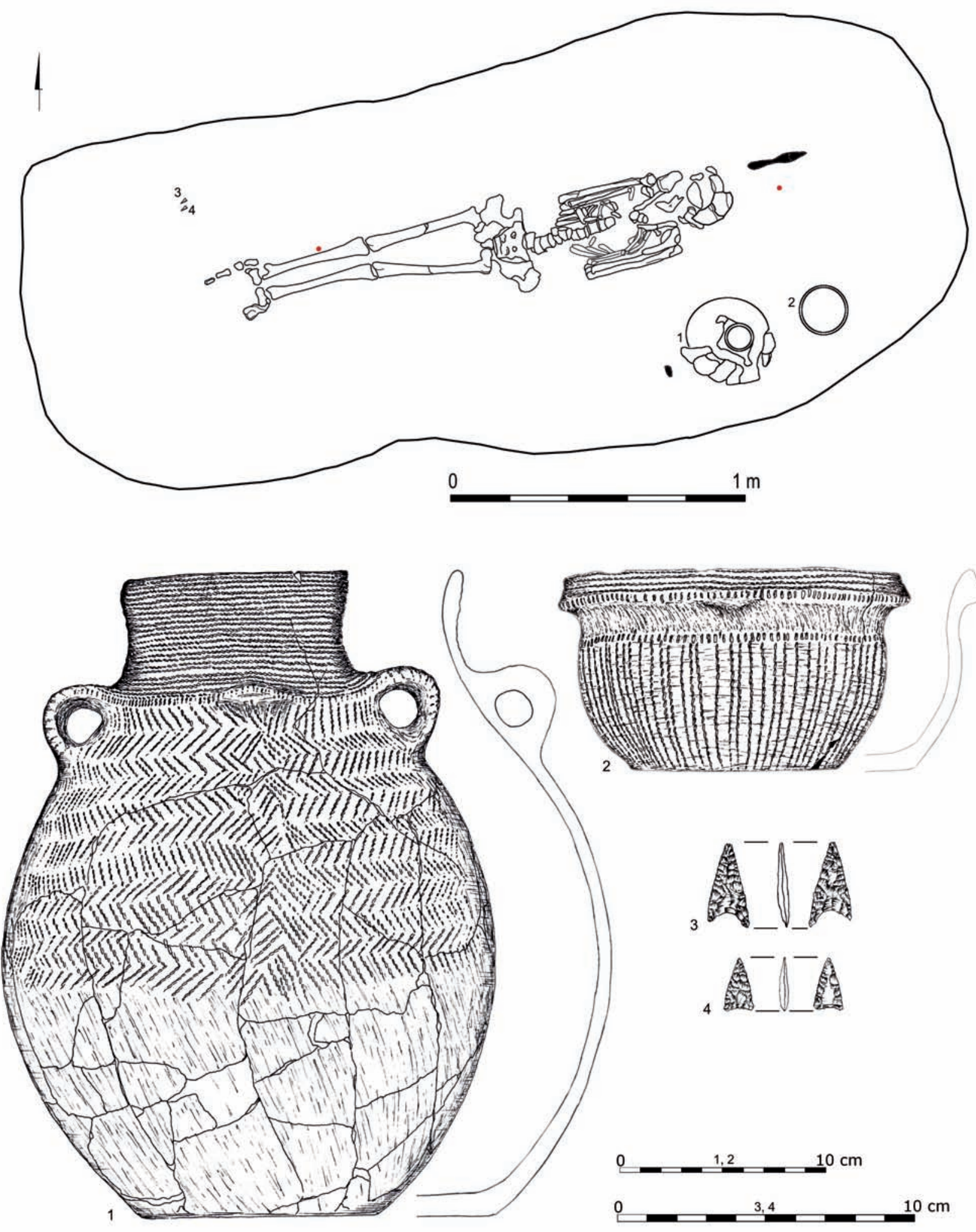

Ryc. 11. Rogalin stan. 15. Plan grobu 16 z wyposażeniem. Rys. B. Bartecki

Fig. 11. Rogalin site 15. Plan of grave 16 with furnishings. Figure by B. Bartecki 

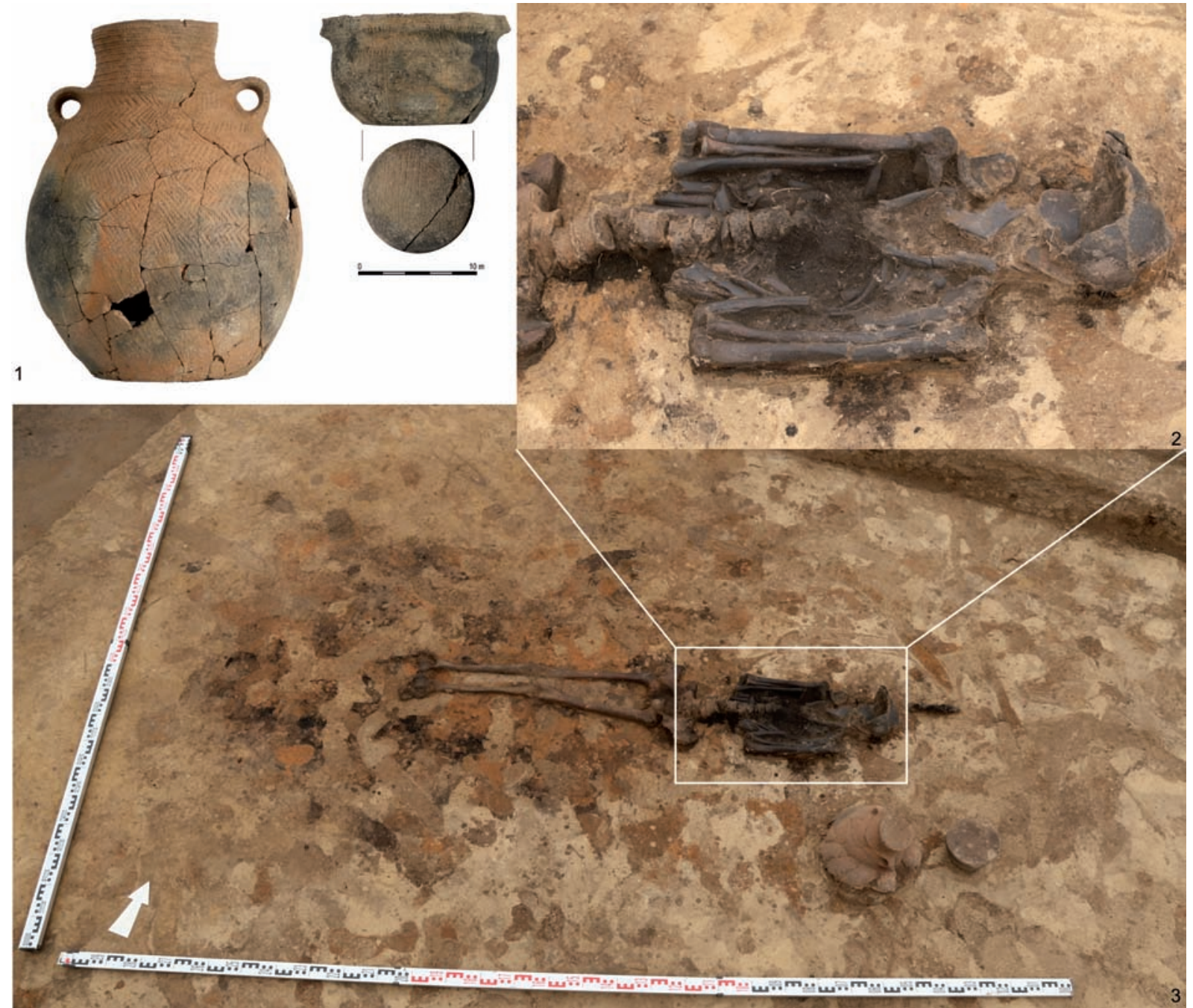

Ryc. 12. Rogalin stan. 15. Grób 15: 1 - naczynia gliniane; 2 - zbliżenie na górną część szkieletu; 3 - plan grobu. Fot. A. Hyrchała

Fig. 12. Rogalin site 15. Grave 15: 1 - clay pots; 2 - close-up of the upper part of the skeleton; 3 - plan of the grave. Photo by A. Hyrchała

morfologicznym są to formy powszechne na stanowiskach kultury strzyżowskiej. Jednak na szczególną uwagę zasługuje waza $\mathrm{z}$ grobu $\mathrm{nr} 15$, ze względu na niespotykane dotąd wśród naczyń strzyżowskich wykończenie powierzchni. Ścianki naczynia od dna aż po górną część brzuśca są dookolnie kanelurowane w układzie poziomym. W górnej części naczynie jest charakterystycznie ornamentowane odciskami sznura, na pogrubionym wylewie i szyi w układzie liniowym od zewnętrznej strony, a od wewnętrznej ukośnymi kreskami. Nie ma dla niego analogii wśród opublikowanych naczyń kultury strzyżowskiej. Do wyrobu naczyń stosowano glinę z drobnoziarnistą domieszką w postaci thucznia granitowego. Ceramika stanowiąca wyposażenie grobowe, często cechuje się słabym wypałem.

\section{Zabytki krzemienne}

Powszechne i charakterystyczne dla obrządku pogrzebowego kultury strzyżowskiej jest wyposażanie zmarłych w narzędzia z krzemienia wołyńskiego, często w postaci sierpów, rzadziej płoszczy, siekier czy grocików, nieraz nawet noszących ślady substancji, za pomocą której mocowane były do promieni strzał. W trzech omawianych pochówkach w skład wyposażenia grobowego wchodziły zabytki krzemienne. $\mathrm{W}$ grobie nr 13 bezpośrednio przy szkielecie odkryto odłupek z przyostrzowej części gładzonej siekiery. Przedmiot ten jest interesujący z kilku powodów. Jest to pierwszy fragment siekiery, jaki pojawia się na stanowisku w Rogalinie. Dotychczas siekiery krzemienne odnotowano w wyposażeniu grobowym w Raci- 
borowicach-Kolonii (Ślusarski, Ślusarska-Polańska 1988, 192) i Horodysku (Bargieł 2006a, 360; Libera 2016, 115). Stanowił wyposażenie zaledwie kilkumiesięcznego dziecka, być może należy go traktować jako dar symboliczny. Obecność fragmentu narzędzia krzemiennego w grobie wpisuje się w zaobserwowany wcześniej na stanowisku w Rogalinie zwyczaj celowego uszkadzania przedmiotów krzemiennych (Hyrchała 2015b, 50). Badania traseologiczne zabytków z zespołów grobowych kultury strzyżowskiej wskazały, że wierzchołki sierpów były niszczone bezpośrednio przed złożeniem do grobu, bowiem na złamanych partiach tych przedmiotów brak charakterystycznych wyświeceń, powstałych w wyniku ich użytkowania. Dotychczas w grobach odkrywano niemal całe narzędzia, pozbawione jedynie części wierzchołkowych. Natomiast w przypadku grobu nr 13, to właśnie odbita od siekiery część spoczywała przy zmarłym dziecku. W grobie nr 15 przy górnej części szkieletu znaleziono krzemienny grocik strzały, smukły, o lekko podciętej podstawie. Natomiast w grobie nr 16, na wysokości stóp zmarłego, odkryto dwa kolejne grociki. Jest to trzeci pochówek na stanowisku wyposażony $\mathrm{w}$ tego typu przedmioty. W grobie nr 10 odkryto 16 egzemplarzy w zwartym zespole z krzemiennym sierpem, płoszczem i wióroodłupkiem (Hyrchała 2015a, 66-68).

\section{Zabytki z kości zwierzęcych}

Przedmioty wykonane z kości zwierzęcych stosunkowo często odkrywane są $\mathrm{w}$ grobach kultury strzyżowskiej. W przypadku cmentarzyska w Rogalinie ich liczba jest jednak niewielka. W ostatnim sezonie badawczym odkryto trzy szpile kościane. Dwie $\mathrm{z}$ nich, w tym w całości zachowana forma $\mathrm{z}$ otworkiem, znajdowały się $\mathrm{w}$ grobie $\mathrm{nr} 13$, bezpośrednio przy szkielecie dziecka. Trzecia została znaleziona przy szkielecie dorosłego mężczyzny, w grobie nr 15 . Dotychczas zabytki tej kategorii odkryto w dwóch grobach z Rogalina. W pochówkach kultury strzyżowskiej sporadycznie spotykane są również zawieszki lub aplikacje wykonywane z szabli dzika. W grobie nr 13 odkryto kolejną na tym stanowisku zawieszkę z zachowanymi częściowo dwoma otworkami, służącymi do zawieszenia na szyi. Poprzednia została znaleziona $\mathrm{w}$ grobie $\mathrm{nr} 3$, w którym pochowano dziewczynkę w wieku 9-10 lat (Hyrchała 2015a, 56). Analogiczny przedmiot w zestawie z paciorkami fajansowymi znaleziono na cmentarzysku w Hrubieszowie-Podgórzu, również w grobie dziecka (Banasie- wicz 1990, 219, 221, ryc. 6:4). Kolejne zabytki z szabli dzika to fragmentarycznie zachowane aplikacje z grobu $\mathrm{nr} 14$. W tym samym grobie znaleziono również prostokątną aplikację z kości z czterema przewierconymi otworkami. Analogie do tego typu zabytków można odnaleźć na przykład na stanowisku w Gródku (Panasiewicz 1995, 6-8).

\section{Paciorki fajansowe i zabytki z muszli}

We wszystkich omawianych grobach odkryto paciorki fajansowe. Są one najliczniejszą kategorią zabytków na cmentarzyskach kultury strzyżowskiej. W grobach nr 13, 15 i 16 znaleziono po kilka sztuk, natomiast w grobie nr 14 odkryto ich aż $51 \mathrm{i}$ jest to drugi, pod względem ilości paciorków fajansowych, pochówek na tym stanowisku. Najwięcej, bo 90 sztuk odkryto w bogato wyposażonym grobie nr 6 (Hyrchała, 2015a, 61). Paciorki są barwy białej, jasnozielonej lub szaroczarnej (grób nr 14) prawie wszystkie cylindryczne (oprócz jednego dwusegmentowego), o wymiarach $0,4-0,9 \mathrm{~cm}$.

$\mathrm{Z}$ grobu $\mathrm{nr} 14$ pochodzi również zawieszka z muszli z przewierconym otworem. Wcześniej tego typu przedmioty odnotowano w grobach $\mathrm{nr} 6$ i 11 (Hyrchała 2015a, 76), gdzie jednak muszle były w całości z przewierconymi trzema otworkami. Muszla z grobu nr 14 jest wyjątkowa ze względu na jej zeszlifowanie do formy okrągłej tarczki. Dotychczas takie zawieszki wykonywane były z kości zwierzęcych lub rogu, odnaleziono je m.in. w Hrubieszowie-Podgórzu (Niedźwiedź et al. 2001, 24, tabl. 4: 4, 5), Raciborowicach-Kolonii (Ślusarski, Ślusarska-Polańska 1988, 174), czy w Świerszczowie (Jączek 2014, 4).

\section{ANALIZA OBRZĄDKU POGRZEBOWEGO}

Cmentarzysko w Rogalinie wpisuje się w kanon stanowisk sepulkralnych kultury strzyżowskiej w regionie hrubieszowskim (ryc. 13). Założono je na południowym stoku wyniesienia, opadającym łagodnie w stronę doliny Bugu. Groby lokowano wzdłuż skłonu Grzędy Horodelskiej na linii wschód-zachód. Odległość pomiędzy najdalej wysuniętymi pochówkami wynosi ponad 70 metrów i jak dotąd nie określono granic cmentarzyska. Wśród przebadanych dotychczas 16 grobów odnotowano wyraźne skupiska: zachodnie (groby nr 2-7) i wschodnie (groby nr 9-11) (Hyrchała 2015a, 72-73). Fakt ten może wiązać się ze 


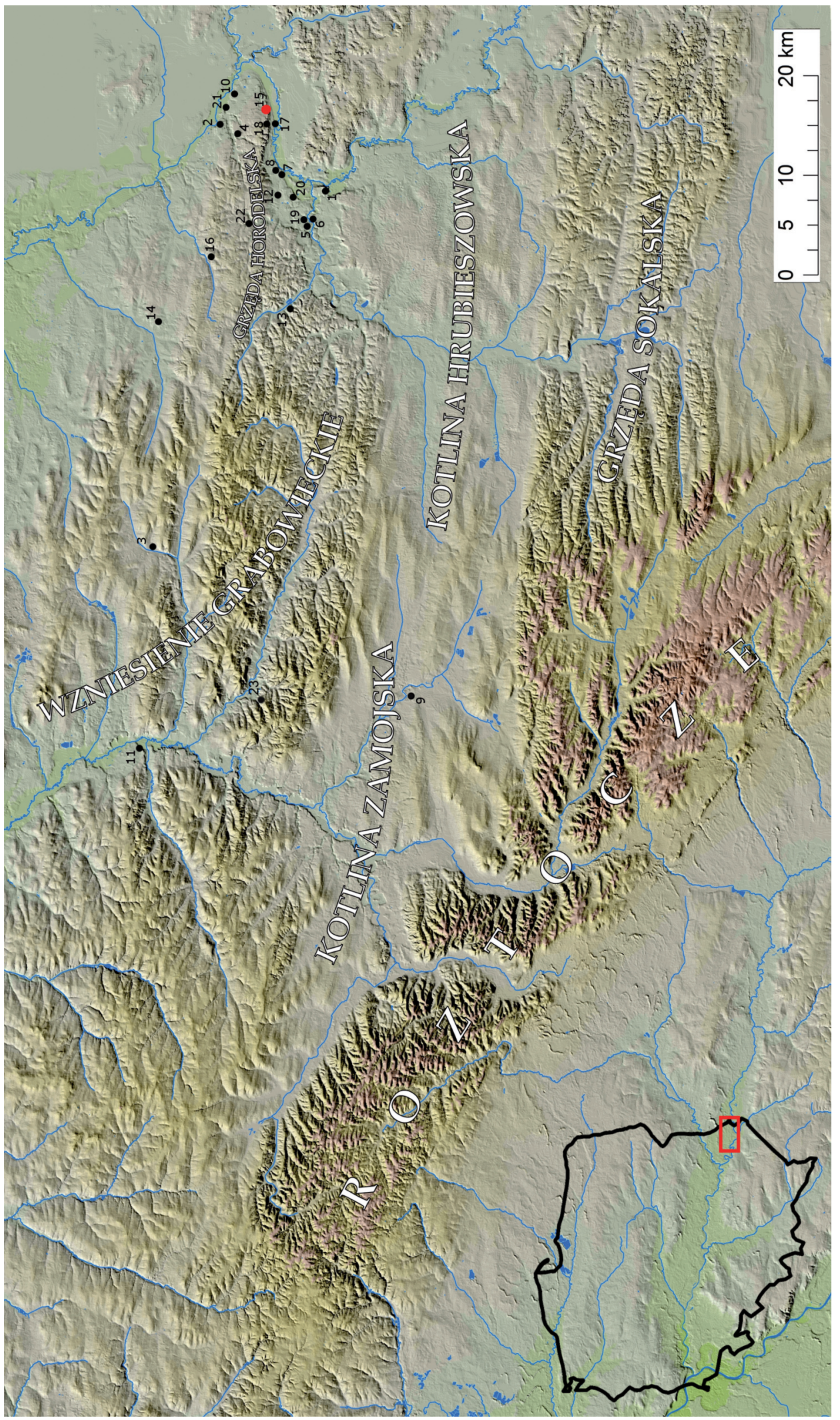

获的

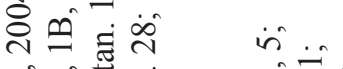

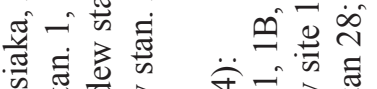

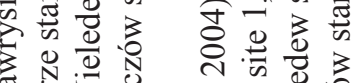

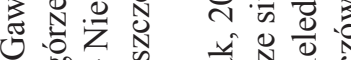

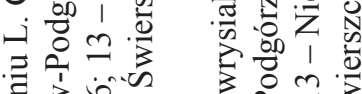

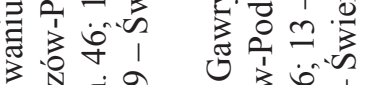

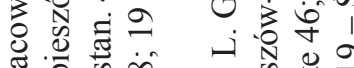

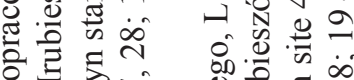

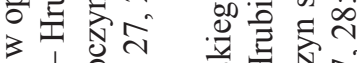

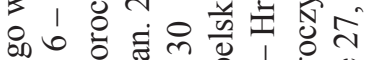

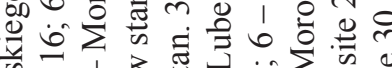

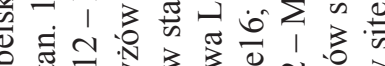

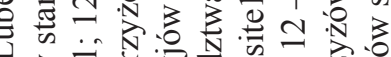

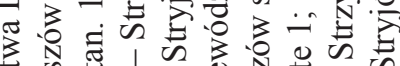

然

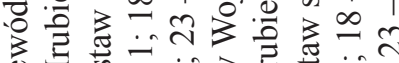

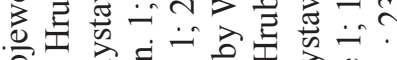

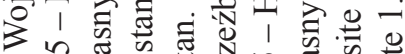

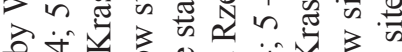

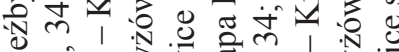

虫

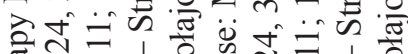

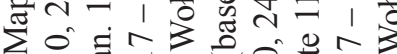

西

त्ष्ठ

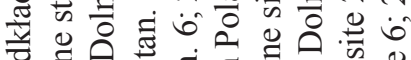

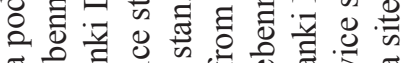

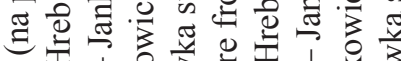

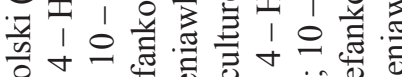

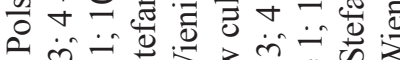

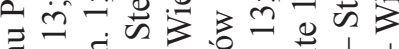

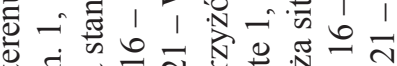

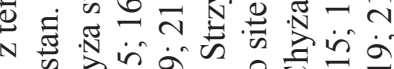

ब.

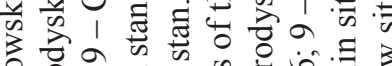

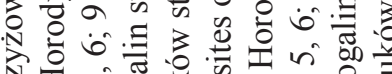

的政

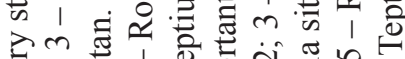

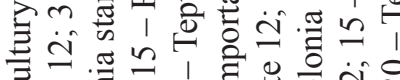

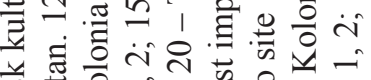

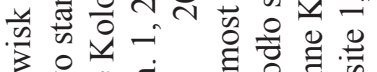

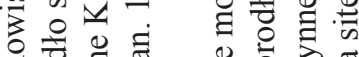

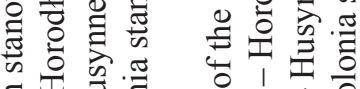

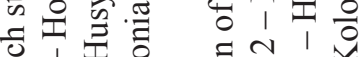

小

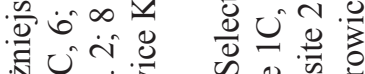

.

उ

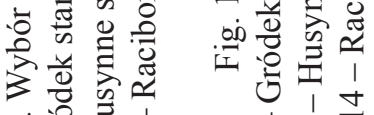

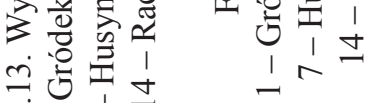

宓 1 
świadomym tworzeniem kwater rodzinnych oraz celowym rozplanowaniem miejsc grzebalnych z zachowaniem odległości pomiędzy kwaterami. Badania genetyczne pochówków odkrytych we wcześniejszych sezonach wykazały takie prawidłowości. Mężczyźni ze skupiska w części wschodniej (groby nr 9 i 10), pochowani obok siebie w dwóch oddzielnych jamach, posiadali wspólnego męskiego przodka i mogli być braćmi lub bliskimi kuzynami. Dodatkowo w stopach osobnika z grobu nr 10 odkryto pojedyncze kości (lewa kość łokciowa i pierwsze prawe żebro) należące do jego kilkuletniej córki. Wykazano także pokrewieństwo pomiędzy zmarłymi z grobów nr 3, 5, 6 i 8 (AbreuGłowacka 2015, 174-177). Pochówek nr 13, zlokalizowany w bezpośrednim sąsiedztwie grobów $\mathrm{nr} 10$ i 11, należy dodać do skupiska wschodniego. Dostępny materiał genetyczny nie pozwolił na określenie pokrewieństwa. Natomiast w świetle dotychczasowych badań pochówki nr 14 i 16 zdają się tworzyć nowe skupisko grobów o wspólnych cechach związanych ze stosowaniem ognia w obrządku pogrzebowym. W przypadku pochówku nr 15 na obecnym etapie badań nie można niestety stwierdzić, czy wchodzi w skład kolejnych skupisk grobów, gdyż jego najbliższe sąsiedztwo nie zostało jeszcze przebadane. Niemniej jednak, nawet na przykładzie niewielkiego cmentarzyska w Rogalinie, można z dużą dozą prawdopodobieństwa mówić o nieuchwytnych do niedawna regułach organizowania przestrzeni grzebalnej w oparciu o więzy krwi.

Jamy grobowe usytuowane były na osi wschódzachód i kształtem zbliżone do prostokąta o zaokrąglonych narożnikach, jedynie w przypadku grobu nr 13 jama miała nieregularny kształt zbliżony do owalnego. Odkryty w niej szkielet dziecka należał do najmłodszego osobnika wśród opublikowanych dotąd grobów kultury strzyżowskiej. Uwagę zwraca również fakt bogatego wyposażenia kilkumiesięcznego dziecka w różne kategorie darów grobowych. Obok opisanych powyżej naczyń, interesująca jest również obecność dwóch kościanych szpil, zlokalizowanych w okolicach czaszki. Domniemywać można, że mogły one spinać całun owijający ciało bądź były elementem stroju pogrzebowego. Również zawieszka z kła dzika jest elementem wyjątkowym. Wydaje się prawidłowością, w obrządku pogrzebowym kultury strzyżowskiej, wyposażanie $\mathrm{w}$ te właśnie przedmioty najmłodszych dzieci.

Szczególnie trudne w rekonstrukcji wybranych elementów obrządku pogrzebowego kultury strzyżowskiej są dwa z zarejestrowanych w ostatnich sezo- nach badawczych. Wśród wszystkich przebadanych dotychczas pochówków wyróżniają się jamy grobów nr 14 i 16. Obecność zwartej warstwy polepy w stropie jamy grobowej, przykrywającej silnie przepalone szkielety, świadczy o celowym stosowaniu zabiegów ciałopalnych. Odnotowane na spodniej stronie warstwy polepy odciski pozostawione przez rośliny oraz analiza nawarstwień pozwalają na próbę odtworzenia rytuału, w którym ogień odgrywał istotną rolę. Do jamy grobowej składano zmarłego wraz z wyposażeniem, a następnie rozpalano w niej ogień. Stan zachowania szczątków kostnych z grobu nr 16 zdaje się w dobry sposób obrazować różnicę w stopniu nadpalenia ciała w trakcie rytuału. Dolna część szkieletu od kości miednicy wraz z kośćmi kończyn dolnych są barwy ciemnobrązowej, z kolei klatka piersiowa, kości kończyn górnych i czaszka, mają barwę jednolicie czarną. Przyczyna tych różnic zdaje się wynikać z czasu oddziaływania wysokiej temperatury na poszczególne części ciała zmarłego i tym samym ze stopnia zwęglenia tkanek miękkich. Kości szkieletu o barwie ciemnobrązowej i spieczonej strukturze zostały zasypane warstwą ziemi przed całkowitym zwęgleniem tkanek miękkich. W obrębie górnej części ciała temperatura zapewne była zdecydowanie wyższa, przez co odsłoniła kości. Zasypanie jamy grobowej w momencie, gdy panuje w niej temperatura kilkuset stopni, można porównać do procesu wypalania naczyń glinianych w atmosferze redukcyjnej. W chwili gwałtownego odcięcia tlenu, powstający tlenek powoduje trwałe zabarwienie szczątków kostnych na czarno. Cechy kości, szczególnie z górnej części szkieletu z grobu nr 16 poddanych takiemu zabiegowi, obrazowo można porównać do cech fizycznych dobrze wypalonej ceramiki, która uderzona twardym przedmiotem wydaje charakterystyczny dźwięk.

Po uprzednim nadpaleniu ciała dokładano do paleniska kolejną porcję drewna w postaci gałęzi z liśćmi i zasypywano lessem, który po wypaleniu utworzył zwartą warstwę polepy ${ }^{1}$. Jej grubość oraz omówiony powyżej stopień przepalenia kości świadczą o długotrwałym oddziaływaniu wysokiej temperatury. W dalszej części obrzędu pogrzebowego bezpośrednio nad zasypaną już jamą grobową kontynuowano palenie ogniska. Jest to nowa sytuacja na cmentarzysku w Rogalinie. Do tej pory odkryto jeden pochówek noszący ślady nadpalenia (grób nr 6) (Hyrchała 2015a,

1 Analizy wykonała prof. dr hab. Krystyna Wasylikowa z Instytutu Botaniki im. W. Szafera PAN, za co serdecznie dziękuję. 
73), jednak wypełnisko jamy grobowej nie zawierało polepy i węgli, a grób został również wyrabowany w starożytności.

Przedstawione okoliczności, w jakich przebiegał rytuał pogrzebowy, sprawiły, że w omawianych grobach zachowały się fragmenty zwęglonego drewna. Dzięki temu udało się pozyskać i oznaczyć ${ }^{2}$ próby węgli drzewnych. Wśród nich zarejestrowano dwa taksony: sosna zwyczajna Pinus sylvestris oraz dąb Quercus sp. W grobie nr 14 znaleziono jedynie szczątki dębu, natomiast $\mathrm{w}$ grobie nr 16 znaleziono oba taksony, choć sosna była częściej spotykana. Stan zachowania nadpalonych kości uniemożliwił wykonanie dla nich datowań radiowęglowych. Posłużyły do tego próby węgli. Na innych stanowiskach kultury strzyżowskiej odnotowywano także wcześniej pochówki noszące ślady kontaktu z ogniem, jednak do chwili przebadania i przeanalizowania pochówków z Rogalina wiedza na ten temat była fragmentaryczna. Potwierdzeniem analogicznych zabiegów są groby nr 3 i 16 z Raciborowic Kolonii, gdzie wypełnisko jamy stanowiła ziemia przemieszana z popiołem, węglami drzewnymi i bryłami polepy oraz, dodatkowo w grobie nr 16, znaleziono skupisko przepalonej gliny i ślady zwęglonej belki (Ślusarski, Ślusarska-Polańska 1988, 188).

Niemniej interesujące są kwestie związane z sygnalizowanym, ale niepotwierdzonym dotychczas w literaturze celowym naruszaniem jam grobowych (Bargieł 2006b, 70; Koman 1991, 14). W nawiązaniu do dyskusji na ten temat należy zwrócić uwagę na interesujące ułożenie kości szkieletu grobu nr 15. Pochowano w nim dorosłego mężczyznę. Kości górnej części szkieletu były znacząco przemieszczone. Jedynie kończyny dolne leżały w porządku anatomicznym. Choć strop jamy grobowej naruszony został przez maszyny rolnicze, to na poziomie zalegania szkieletu nie odnotowano śladów zniszczeń powodowanych głęboką orką. Tym samym kości górnej części szkieletu nie mogły zostać naruszone współcześnie. Grób ten został ponownie otwarty jeszcze w pradziejach. Podobna sytuacja odnotowana została na stanowisku nr 31 w Hrebennem (Koman 1991, 14), czy też na stanowisku nr 1C w Gródku (Głosik 1958, 162). We wspomnianych przypadkach przemieszana jest górna część szkieletu, natomiast nogi pozostawione są w porządku anatomicznym. Przykłady te wskazują na zwyczaj

2 Analizy wykonała dr Magdalena Moskal-del Hoyo z Instytutu Botaniki im. W. Szafera PAN, za co serdecznie dziękuję. ponownego otwierania grobów w stosunkowo krótkim okresie od pochówku. Precyzja dokonania wkopu w okolicę klatki piersiowej może świadczyć, że pochówki w obrębie cmentarzyska mogły być oznaczone na powierzchni w sposób obecnie niemal nieuchwytny, być może nasypami ziemnymi lub innymi, np. drewnianymi znacznikami. Zaobserwowanie tego typu praktyk, w związku z ogromnym zniszczeniem stanowisk archeologicznych przez uprawę roli, jest obecnie bardzo trudne. Jednym z niewielu przykładów rzucających nieco światła na sposób oznaczania pochówku w przestrzeni grzebalnej jest zniszczony przez orkę grób nr 8 z Rogalina. Szczątkowo zachowały się ślady po rowku okalającym jamę grobową, co może sugerować pochówek pod kurhanem średnicy około $10 \mathrm{~m}$. Nie można jednoznacznie stwierdzić, czy wkopy miały charakter rabunkowy, czy stanowiły ingerencję w obrębie jamy grobowej w celu dopełnienia rytuału pogrzebowego.

\section{DATOWANIE}

Dla grobów nr 14-16 uzyskano pięć oznaczeń radiowęglowych: dla węgli drzewnych $\mathrm{z}$ jam grobowych nr 14 i $16^{3}$ oraz dla kości szkieletu z grobu $\mathrm{nr} 15^{4}$ (tabela 1). Z grobu nr 14 datowano węgle pochodzące z dębu. Otrzymano jedną z najmłodszych dat dla kultury strzyżowskiej, zamykającą się w przedziale $3270 \pm 60$ BP. Natomiast $z$ grobu nr 16 pochodziły próby węgli z sosny i obie wykonane daty znacząco różnią się od siebie. Jedna $\mathrm{z}$ nich mieści się $\mathrm{w}$ przedziale $3560 \pm 90$ BP (datę tę można pominąć w modelowaniu ze względu na prawdopodobny efekt starego drewna), natomiast druga jest już zbliżona wartością do wyników z grobu nr 14 i wynosi $3430 \pm 40$ BP. Daty $\mathrm{z}$ grobu $\mathrm{nr} 14 \mathrm{w}$ procesie modelowania zamykają się w przedziale 1700-1675 BC (ryc. 14) i są to najmłodsze daty kultury strzyżowskiej. Natomiast data dla grobu nr 15 okazuje się być najstarszą z dotychczas uzyskanych dla cmentarzyska w Rogalinie, gdyż z prawdopodobieństwem $68,2 \%$ odnosi się do przedziału 1947-1782 BC. W literaturze przedmiotu funkcjonują już wyniki z grobów nr 4 i 10 z tego stanowiska (Hyrchała 2015a, 77), a także z pięciu grobów kultury strzyżowskiej z cmentarzyska w Horodysku

3 Datowania wykonano w Laboratorium Datowań Bezwzględnych Marek Krąpiec.

4 Datowania wykonano w Poznańskim Laboratorium Radiowęglowym. 
Tabela 1. Datowania radiowęglowe grobów kultury strzyżowskiej

Table 1. Radiocarbon datings for graves of Strzyżów culture

\begin{tabular}{|c|c|c|c|c|c|c|}
\hline Stanowisko & $\begin{array}{l}\text { Numer } \\
\text { obiektu }\end{array}$ & $\begin{array}{c}\text { Numer } \\
\text { laboratoryjny }\end{array}$ & $\begin{array}{c}\text { Datowany } \\
\text { materiał }\end{array}$ & $\begin{array}{l}\text { Wiek } \\
{ }^{14} \mathrm{C} \mathrm{BP}\end{array}$ & $\begin{array}{c}\text { Wiek absolutny } \\
\text { BC }(68,2 \%)\end{array}$ & Literatura \\
\hline $\begin{array}{l}\text { Horodysko } \\
\text { stan. } 13\end{array}$ & 1 & Poz-20510 & $\begin{array}{l}\text { Kość } \\
\text { ludzka }\end{array}$ & $3460 \pm 35$ & $1880-1690$ & $\begin{array}{l}\text { Libera } \\
2016\end{array}$ \\
\hline $\begin{array}{l}\text { Horodysko } \\
\text { stan. } 13\end{array}$ & 2 & Poz-20511 & $\begin{array}{l}\text { Kość } \\
\text { ludzka }\end{array}$ & $3620 \pm 35$ & 2030-1935 & $\begin{array}{l}\text { Libera } \\
2016\end{array}$ \\
\hline $\begin{array}{l}\text { Horodysko } \\
\text { stan. } 13\end{array}$ & 3 & Poz-20512 & $\begin{array}{l}\text { Kość } \\
\text { ludzka }\end{array}$ & $3475 \pm 35$ & $1880-1740$ & $\begin{array}{l}\text { Libera } \\
2016\end{array}$ \\
\hline $\begin{array}{l}\text { Horodysko } \\
\text { stan. } 13\end{array}$ & 5 & Poz-20513 & $\begin{array}{l}\text { Kość } \\
\text { ludzka }\end{array}$ & $3500 \pm 30$ & $1890-1770$ & $\begin{array}{l}\text { Libera } \\
2016\end{array}$ \\
\hline $\begin{array}{l}\text { Horodysko } \\
\text { stan. } 13\end{array}$ & 6 & Poz-66253 & $\begin{array}{l}\text { Kość } \\
\text { ludzka }\end{array}$ & $3460 \pm 35$ & $1876-1696$ & $\begin{array}{l}\text { Libera } \\
2016\end{array}$ \\
\hline $\begin{array}{l}\text { Rogalin } \\
\text { stan. } 15\end{array}$ & 4 & Poz-54178 & $\begin{array}{l}\text { Kość } \\
\text { ludzka }\end{array}$ & $3495 \pm 30$ & $1880-1771$ & $\begin{array}{l}\text { Hyrchała } \\
2015 a\end{array}$ \\
\hline $\begin{array}{l}\text { Rogalin } \\
\text { stan. } 15\end{array}$ & 10 & Poz-54179 & $\begin{array}{l}\text { Kość } \\
\text { ludzka }\end{array}$ & $3405 \pm 35$ & $1747-1643$ & $\begin{array}{l}\text { Hyrchała } \\
\text { 2015a }\end{array}$ \\
\hline $\begin{array}{l}\text { Rogalin } \\
\text { stan. } 15\end{array}$ & 14 & MKL-3741 & $\begin{array}{l}\text { Węgiel } \\
\text { drzewny }\end{array}$ & $3350 \pm 40$ & $1692-1563$ & \\
\hline $\begin{array}{l}\text { Rogalin } \\
\text { stan. } 15\end{array}$ & 14 & MKL-3742 & $\begin{array}{l}\text { Węgiel } \\
\text { drzewny }\end{array}$ & $3270 \pm 60$ & $1621-1465$ & \\
\hline $\begin{array}{l}\text { Rogalin } \\
\text { stan. } 15\end{array}$ & 15 & Poz-81218 & $\begin{array}{l}\text { Kość } \\
\text { ludzka }\end{array}$ & $3550 \pm 35$ & $1947-1782$ & \\
\hline $\begin{array}{l}\text { Rogalin } \\
\text { stan. } 15\end{array}$ & 16 & MKL-3740 & $\begin{array}{l}\text { Węgiel } \\
\text { drzewny }\end{array}$ & $3430 \pm 40$ & 1866-1666 & \\
\hline $\begin{array}{l}\text { Rogalin } \\
\text { stan. } 15\end{array}$ & 16 & MKL-3743 & $\begin{array}{l}\text { Węgiel } \\
\text { drzewny }\end{array}$ & $3560 \pm 90$ & 2024-1771 & \\
\hline
\end{tabular}

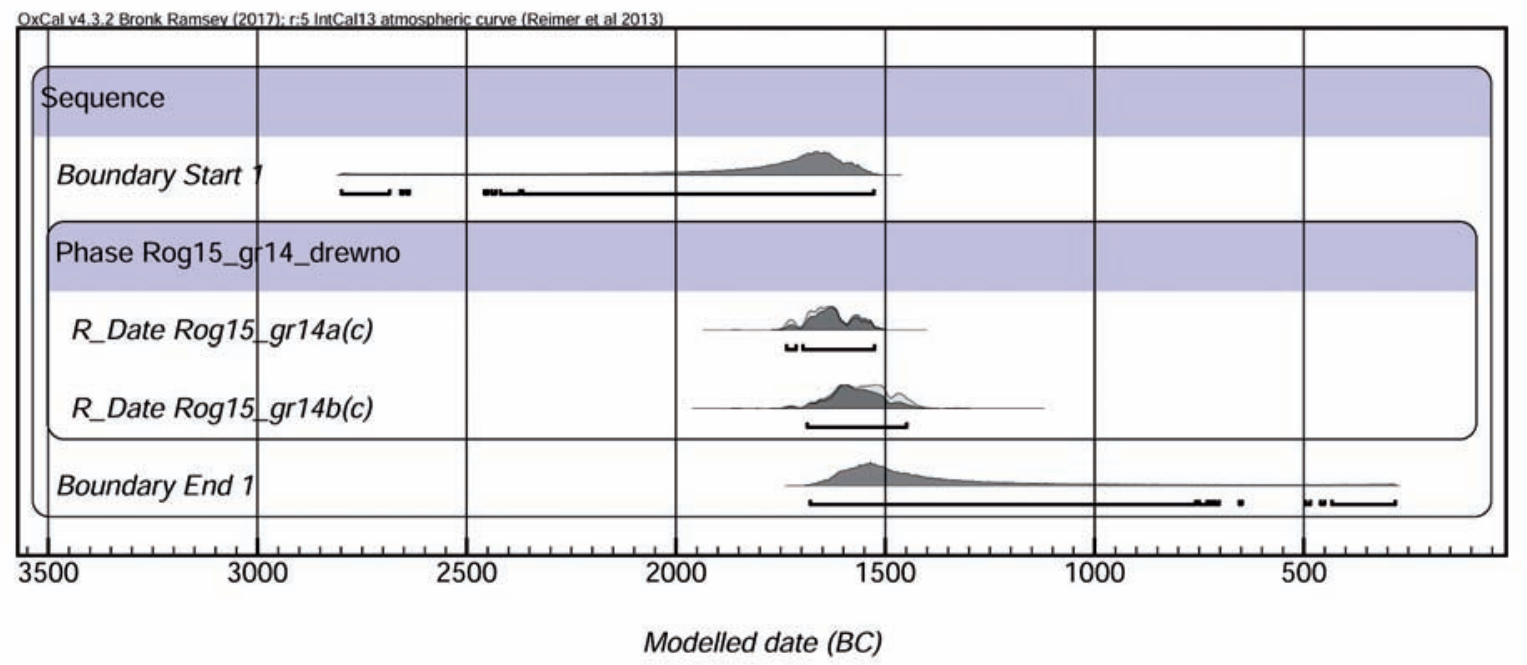

Ryc. 14. Model datowania grobu 14 ze stanowiska $15 \mathrm{w}$ Rogalinie. W oparciu o program OxCal v4.3.2. Bronk Ramsey (2017)

Fig. 14. Dating model of grave 14 from site 15 in Rogalin. Based on OxCal v4.3.2. Bronk Ramsey (2017) 


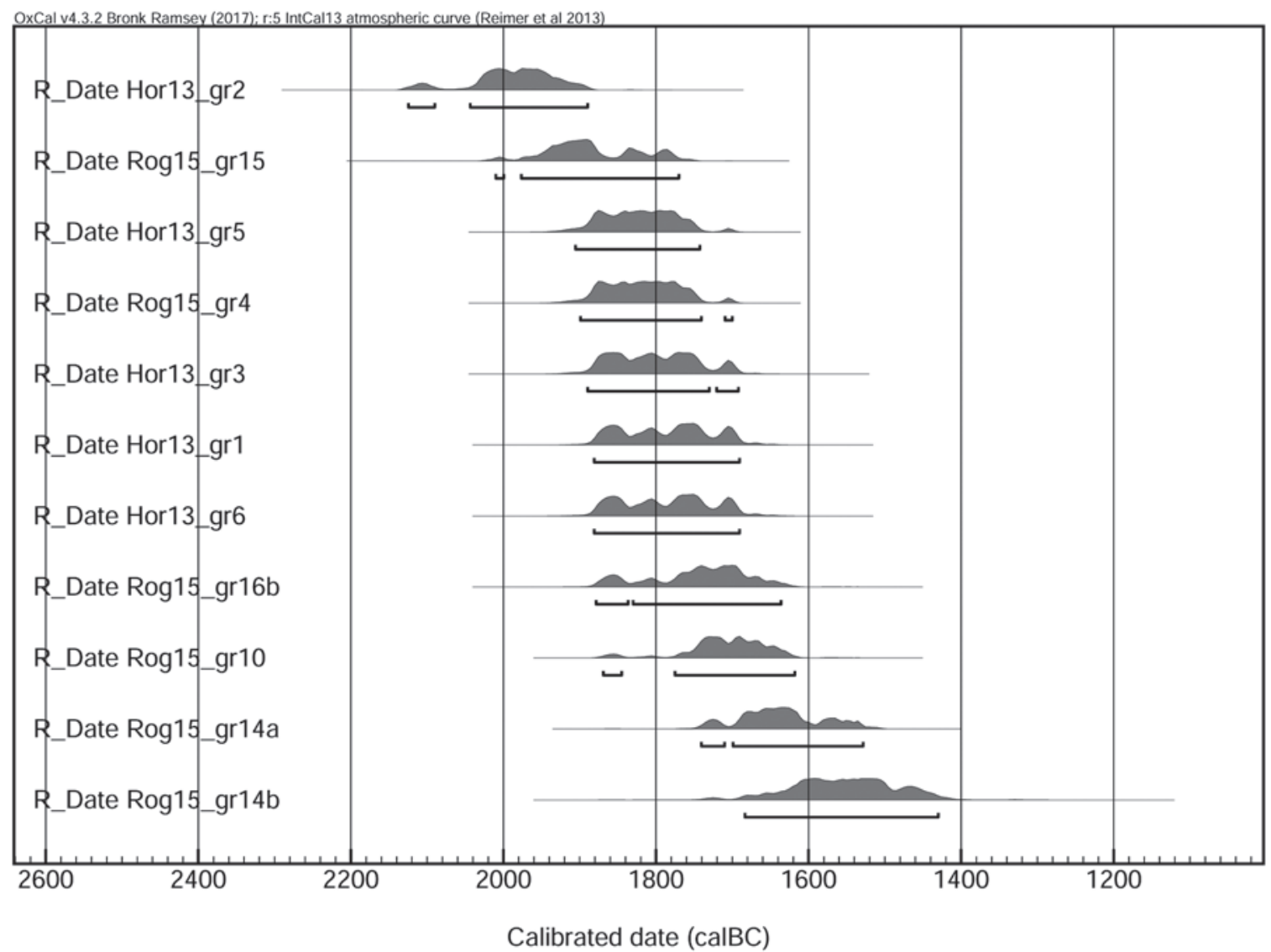

Ryc. 15. Zestawiene oznaczeń radiowęglowych dla grobów kultury strzyżowskiej. W oparciu o program OxCal v4.3.2. Bronk Ramsey (2017)

Fig. 15. Compilation of radiocarbon datings for graves of the Strzyżów culture. Based on OxCal v4.3.2. Bronk Ramsey (2017)

(Libera 2016, 122-126) (ryc. 15, tabela 1) oraz datowania dla wyjątkowego pod-kurhanowego cmentarzyska w Stryjowie (Budziszewski et al. 2016, 403). Na wspomnianym stanowisku w Stryjowie odkryto pod kurhanem nr 1 cztery pochowki, które, przy założeniu jednoczasowości, mieszczą się w przedziale 20221970 BC, co może stanowić w opinii P. Włodarczaka „inicjalny etap nurtu strzyżowskiego” (2016, 544). Na stanowisku w Horodysku tylko dla grobu nr 2 uzyskano podobną datę, natomiast pozostałe pochówki były zdecydowanie młodsze. W świetle uzyskanych oznaczeń radiowęglowych można wysnuć wniosek, że cmentarzysko w Rogalinie mogło być użytkowane przez dwa lub nawet trzy stulecia.

\section{PODSUMOWANIE}

Zaprezentowane pochówki z cmentarzyska kultury strzyżowskiej w Rogalinie na tle wyników badań na innych stanowiskach w regionie hrubieszowskim dostarczyły interesujących informacji na temat obrządku pogrzebowego kultury strzyżowskiej. Każdy z omówionych powyżej przypadków poszerzył stan wiedzy na temat zagadnień związanych z traktowaniem zmarłych we wczesnej epoce brązu. Odkrycie $\mathrm{w}$ bogato wyposażonym grobie $\mathrm{nr} 13$ najmłodszego osobnika wśród wszystkich znanych z literatury pozwala stwierdzić, że nawet kilkumiesięczne dzieci traktowane były jako pełnoprawni członkowie społeczności. Składane były do grobów wraz z wyposażeniem, zgodnie z obowiązującym obrządkiem pogrzebowym. Istotną rolę w zrozumieniu reguł organizacji przestrzennej cmentarzysk dostarczają badania genetyczne. Kwatery rodzinne, czy celowe dokładanie do grobów pojedynczych szczątków innych osobników, to spostrzeżenia, które nie byłyby możliwe bez kompleksowego podejścia do analiz antropologicznych. Milowym krokiem w zrozumieniu zmian zachodzących w obrządku pogrzebowym kultury 
strzyżowskiej na przestrzeni kilkuset lat jej funkcjonowania, są odkrycia wyjątkowych pod względem formy pochówku grobów nr 14 i 16. Pozostałości paleniska bezpośrednio w obrębie jamy grobowej, ślady roślin, jakie odcisnęły się na polepie, a przede wszystkim stan zachowania kości poddanych działaniu wysokiej temperatury, pozwoliły podjąć próbę rekonstrukcji rytuałów pogrzebowych, w których ogień odgrywał znaczącą rolę. Uzyskane oznaczenia radiowęglowe pozwalają lokować pochówki noszące ślady nadpalania w młodszej fazie kultury strzyżowskiej, poprzedzającej pojawienie się społeczności wiązanej z kulturą trzciniecką ze środkowego okresu epoki brązu. Natomiast w przypadku grobu nr 15 potwierdzony zwyczaj naruszania pochówku zmarłego już w pradziejach stawia pytanie o cel takich zabiegów. Nie jest bowiem jasne, czy dokonywano go w celach rabunkowych, czy miało to związek z dopełnieniem obrządku pogrzebowego lub innymi czynnościami, których przy obecnym stanie badań nie można jednoznacznie stwierdzić. Z kolei uzyskane datowania radiowęglowe poszerzają stan wiedzy na temat chronologii bezwzględnej i stanowią kolejny punkt odniesienia przy próbie stworzenia precyzyjnej chronologii w obrębie kultury strzyżowskiej.

\section{BIBLIOGRAFIA}

Abreu-Głowacka M. (2015). Badania genetyczne - odkrywanie tajemnic grobów kultury strzyżowskiej. W: A. Hyrchała, B. Bartecki (red.), Wojownik i księżniczka - archeologia - medycyna sadowa - sztuka (170181). Hrubieszów: Muzeum im. ks. St. Staszica.

Banasiewicz E. (1990). Badania na cmentarzysku kultury strzyżowskiej w Hrubieszowie-Podgórzu, woj. Zamość, w latach 1983-1986. Sprawozdania Archeologiczne, 42, 213-226.

Bargieł B. (2006a). Materiały z wielokulturowych stanowisk w Horodysku, pow. chełmski. Archeologia Polski Środkowowschodniej, 8, 351-362.

Bargieł B. (2006b). Kultura strzyżowska w świetle znalezisk grobowych. Wiadomości Archeologiczne, 58, 65-99.

Budziszewski J., Jarosz P., Libera J., Szczepanek A., Witkowska B., Włodarczak P. (2016). Kurhany ze stanowiska 30 w Stryjowie, pow. krasnostawski. W: P. Jarosz, J. Libera, P. Włodarczak (red.), Schyłek neolitu na Wyżynie Lubelskiej (381-409). Kraków: Instytut Archeologii i Etnologii Polskiej Akademii Nauk.

Głosik J. (1958). Groby kultury ceramiki sznurowej w miejscowości Gródek Nadbużny, pow. Hrubieszów. Wiadomości Archeologiczne, 25(1-2), 160-164.

Hyrchała A. (2015a). Wojownik i Księżniczka z Rogalina - nowy rozdział w dziejach badań nad kulturą strzyżowską. W: A. Hyrchała, B. Bartecki (red.), Wojownik i księżniczka - archeologia - medycyna sądowa - sztuka (52-79). Hrubieszów: Muzeum im. ks. St. Staszica.

Hyrchała A. (2015b). Kultura strzyżowska - początek nowej epoki. W: A. Hyrchała, B. Bartecki (red.), Wojow- nik i księżniczka - archeologia - medycyna sądowa - sztuka (32-51). Hrubieszów: Muzeum im. ks. St. Staszica.

Jączek A. (2014). Sprawozdanie z nadzoru archeologicznego nad budowa obwodnicy Hrubieszowa. Hrubieszów: Muzeum im. ks. St. Staszica w Hrubieszowie (maszynopis).

Koman W. (1991). Hrebenne stan. 31, gm. Horodło - grób kultury strzyżowskiej. Sprawozdanie z badań terenowych $w$ województwie zamojskim w 1991 roku, 13-14.

Libera J. (2016). Cmentarzysko szkieletowe z wczesnej epoki brązu. W: T. Dzieńkowski (red.), Horodysko. Od epoki kamienia do wczesnego średniowiecza. Badania 2005-2006 (104-128). Lublin: Instytut Archeologii UMCS.

Lorkiewicz-Muszyńska D., Abreu-Głowacka M., Kociemba W., Glapinski M., Michalak E., Ciesielska M., Hyrchała A. (2021). Materiał kostny z czterech grobów kultury strzyżowskiej wyeksplorowanych w latach 2015-2016 na stanowisku 15 w Rogalinie w świetle badań interdyscyplinarnych, w tym tomie.

Niedźwiedź J., Niedźwiedź E., Prusicka-Kołcon E. (2001). Dokumentacja z archeologicznych badań przedinwestycyjnych podczas budowy domu przy ul. Łakowej w Hrubieszowie-Podgórzu stan. 1. Hrubieszów: Muzeum im. ks. St. Staszica w Hrubieszowie (maszynopis).

Panasiewicz W. (1995). Grób kultury strzyżowskiej z Gródka nad Bugiem, gm. Hrubieszów. Sprawozdania z badań archeologicznych $w$ województwie zamojskim w 1994 roku, 6-8.

Polańska M. (1994). Wyniki badań ratowniczych na stan. 6 w Husynnem Kolonii, gm. Hrubieszów, Sprawozda- 
nia z badań terenowych $w$ województwie zamojskim w 1993 roku, 16-18.

Rodzik J., Mroczek P. (2015). Środowisko geograficzne otoczenia stanowiska archeologicznego w Rogalinie koło Hrubieszowa. W: A. Hyrchała, B. Bartecki (red.), Wojownik i księżniczka - archeologia - medycyna sadowa - sztuka (82-89). Hrubieszów: Muzeum im. ks. St. Staszica.

Ślusarski Z., Ślusarska-Polańska M. (1988). Badania stanowisk kultury strzyżowskiej w Raciborowicach Kolo- nii, woj. Chełm, w latach 1956, 1958 i 1959. Sprawozdania Archeologiczne, 40, 167-196.

Włodarczak P. (2016). Chronologia absolutna cmentarzysk późno- i schyłkowoneolitycznych na Wyżynie Lubelskiej. W: P. Jarosz, J. Libera, P. Włodarczak (red.), Schyłek neolitu na Wyżynie Lubelskiej (537-561). Kraków: Instytut Archeologii i Etnologii Polskiej Akademii Nauk.

\section{ANNA HYRCHAŁA}

\section{PLAYING WITH FIRE - FUNERARY RITUALS OF THE STRZYŻÓW CULTURE AS EXEMPLIFIED BY SELECTED GRAVES FROM THE CEMETERY IN ROGALIN, POLAND*}

\section{SUMMARY}

A multi-cultural site in Rogalin was discovered in 2008. It is located in an exposed area in the edge zone of the Bug valley, on a slope descending to the south, within the mesoregion of the Horodło Plateau, in the western part of the Volhynian Upland. In 2009-2016, regular excavations were conducted at site 15 in Rogalin on behalf of the Rev. Stanisław Staszic Museum in Hrubieszów, with the participation of the Institute of Archaeology of the Maria CurieSkłodowska University in Lublin. During seven seasons, a total area of 1105.5 sq metres within 43 trenches was investigated. The excavations resulted in the discovery of 47 features associated with the Neolithic Funnel Beaker culture and Globular Amphorae culture, the Trzciniec culture dated to the Bronze Age, and 16 graves of the Strzyżów culture from the early Bronze Age. This monograph focuses on graves no. 13-16.

Burial pits at the cemeteries of the Strzyżów culture were oriented mainly along an east-west axis. The deceased, buried along with grave goods, were placed in graves in supine position. In several cases, however, interesting funeral

* The paper presents the results of research conducted as part of the project entitled "The least known among the most interesting - funeral rites of the Strzyżów culture" financed by the National Science Centre, Poland, granted on the basis of decision no. 2015/17/HS3/02865. practices deviating from this principle have been observed. The literature on the subject features individual instances, and describes skeletons with traces of burning and reports burnt wood, fragments of coals, and daub in the filling of burial pits (Ślusarski, Ślusarska-Polańska 1988, 181, 188; Polańska 1994, 16-17). Graves of the Strzyżów culture investigated in Rogalin in 2015-2016 (graves no. 13-16, Fig. 3) are the major focus of this paper and provide new information about the reconstruction of funerary rites using fire.

Grave 13 contained a skeleton of a child aged Infans I (approx. 6-7 months old) equipped with three vessels, a pendant made of a wild boar's tusk, two bone pins, a faience bead, and a flake of a polished flint axe.

Grave 14 contained 679 burnt fragments of a child's bone aged Infans I/Infans II (approx. 7 years old) and three clay vessels, 51 faience beads, a pendant made of a shell, fragments of multi-drilled plates from a wild boar's tusk, a bone multi-drilled plate, and traces of copper.

Grave 15 included a skeleton of a man aged Maturus (45-55 years old) equipped with two vessels, six faience beads, a bone pin, and a flint arrowhead.

Grave 16 contained a skeleton of an adult individual aged Adultus (25-35 years old) equipped with two vessels, two faience beads, and two flint arrowhead.

The Rogalin cemetery is a classic example of sepulchral sites of Strzyżów culture in the Hrubieszów region 
(Fig. 13). It was established on the southern slope of a hill slightly descending towards the Bug river valley. Graves were located along the slope of the Horodło Plateau on an east-west axis. Following examination of 16 graves, distinct western (graves no. 2-7) and eastern (graves no. 9-11) concentrations were recorded (Hyrchała 2015a, 72-73). It is likely that the communities created family plots intentionally and arranged pits maintaining distances between those plots. Genetic tests conducted for burials discovered in previous seasons have indicated such regularities. Males buried in the eastern concentration (graves no. 9 and 10), laid next to each other in two separate pits, had a common male ancestor and could have been brothers or close relatives. Moreover, near the feet of an individual from grave no. 10, single bones (the left ulna and the first right rib) of his several-year-old daughter were found. Analysis has also determined a relationship between the deceased from graves no. 3, 5, 6, and 8 (Abreu-Głowacka 2015, 174-177). Grave no. 13, located in the immediate vicinity of graves no. 10 and 11 , should be categorized as the eastern concentration. The available genetic material did not allow kinship to be determined. In light of research conducted to date, graves no. 14 and 16 seem to form a new cluster of graves exhibiting common features connected with the use of fire in funerary rituals. These examples from the cemetery in Rogalin make it very likely that the burial ground was organized according to blood ties, a rule that was not defined until recently.

Burial pits were located along an east-west axis, their shapes resembling rectangles with rounded corners. Grave no. 13, of irregular shape resembling an oval, is an exception. A child's skeleton discovered there belonged to the youngest individual ever published among graves of the Strzyżów culture. It is intriguing that this several-monthold child was buried along with various sorts of grave goods. Apart from the above-mentioned pottery, two bone pins were found near the skull. It can be assumed that they were used to pin a shroud wrapping the body, or were elements of burial attire. A pendant made of a boar's tusk is also a unique element. It seems that these articles, regularly laid along with the youngest children, were part of burial rites of the Strzyżów culture.

Among all examined burials, pits of graves no. 14 and 16 are particularly distinctive. The presence of dense daub in the ceiling of a burial pit, covering heavily-burnt skeletons, indicates that cremation practices were employed intentionally. Plant imprints found on the underside of the daub layer and analysis of accumulations of daub and earth enable reconstruction of a ritual in which fire played a significant role. Upon laying the deceased and furnishings in a burial pit, a fire was lit. The condition of skeletal remains from grave no. 16 seems to reflect various degrees to which bodies were burnt while performing the rite. While the lower part of the skeleton, with pelvic bones and limbs, is dark brown, the thorax, upper limbs, and skull are uniformly grey. These discrepancies might be due to the length of exposure of individual parts of the body to heat, and the degree of charring of soft tissues. Dark brown, scorched bones were buried with earth before soft tissues charred completely. The upper part of the body must have been exposed to a much higher temperature, hence the exposed bones. Filling a burial pit at the moment when the temperature reaches several hundred degrees might be compared to the process of firing clay pottery in reducing atmosphere. When oxygen is suddenly cut off, skeletal remains become black as a result of oxidization. After partial burning, another portion of wood (branches with leaves) was added to the fire and covered with loess, which, after burning, formed a layer of daub. Its thickness and the degree of bone burning are indicative of prolonged exposure to high temperature. In the following stage of funerary rites, a fire burnt directly above the buried pit.

In consequence of these burial practices, fragments of charred wood were present in the said graves, owing to which samples of charcoal were acquired and marked. Two taxa were determined among them: Scots pine (Pinius sylvestris) and oak (Quercus sp.). Grave no. 14 contained only remains of oak, while grave no. 16 contained both taxa, with pine being more prevalent.

Another interesting issue is the intentional disturbance of burial pits. This practice has been reported, yet never confirmed in the literature (Bargieł 2006b, 70; Koman 1991, 14). One should emphasize an interesting arrangement of bones in grave no. 15, which contained an adult male. While bones of the upper part of the skeleton were significantly relocated, the lower limbs were in anatomical order. Even though the ceiling of the burial pit was disturbed by agricultural machines, no damage resulting from ploughing has been recorded at the level where the skeleton was placed. Thus, the bones of the upper part of the skeleton could not have been disturbed in modern times, meaning the grave had been reopened in prehistoric times. This example is indicative of the custom of reopening graves relatively shortly after the burial. The precision with which the pit was dug into near the thorax could signify that graves at this cemetery could have been marked in a way which is now elusive, possibly by embankments or wooden tags.

Five radiocarbon dates have been obtained for graves no. 14-16: for charcoals from pits no. 14 and 16, and for skeletal bones from grave no. 15 (Table 1). Oak charcoals from grave no. 14 have also undergone analysis, which provided one of the youngest dates for the Strzyżów culture, 
$3270 \pm 60$ BP. As regards grave no. 16 , the date $3430 \pm 40 \mathrm{BP}$ has been determined for samples of pine coal. Dates for grave no. 14 obtained in the modelling process range between 1700-1675 BC (Fig. 14) and are the youngest dates for the Strzyżów culture. The date obtained for grave no. 15 seem to be the oldest one in the cemetery in Rogalin, as there is $68.2 \%$ probability that is corresponds to 1947 $1782 \mathrm{BC}$.

The research conducted at the cemetery in Rogalin provided interesting information on the burial rites of the Strzyżów culture. The discovery of the richly equipped grave no. 13 of the youngest individual known in the literature enables us to hypothesize that even several-monthold children played an important part in the community and were laid in graves with equipment following the rites practiced. Owing to the discovery of graves no. 14 and 16 , which were unusual in terms of the burial form, the formerly observed custom of using fire for ritual purposes was confirmed. The remains of a pyre directly within a burial pit, and imprints of plants on daub, made it possible to attempt a reconstruction of funeral rites in which fire played a significant role. As regards grave no. 15, the custom of disturbing a grave in prehistory was confirmed. It is not clear whether this practice was performed for plundering purposes, or was connected with a complementary funeral rite. The obtained radiocarbon dates expand our knowledge on the absolute chronology. Grave no. 15 belongs to the older phase of the Strzyżów culture, and graves no. 14 and 16 to the more recent phase of this culture.

Otrzymano (Received): 22.03.2020; zrecenzowano (Revised): 30.04.2020; zaakceptowano (Accepted): 7.05.2020

\section{Adres Autorki:}

Mgr Anna Hyrchała

Dział Archeologiczny Muzeum im. ks. St. Staszica w Hrubieszowie

ul. 3-go Maja 11

22-500 Hrubieszów

e-mail: ahyrchala@gmail.com

iD https://orcid.org/0000-0001-8749-1583 
